\title{
Ecosystem-Based Approaches to Ocean Management in the United States: Weaving Together Multiple Strands
}

\author{
David Fluharty
}

Introduction

The United States has developed a number of approaches that might be collectively characterized as ecosystem-based management for the oceans. Perhaps the most cogent quasi-official statement on what the ecosystem approach to management is comes from the Ecosystem Goal Team of the National Oceanic and Atmospheric Administration (NOAA). 'The term ecosystem approach to management (EAM) was selected by NOAA as a preferable term to ecosystem management (EM) because it reflects the notion that the principle (sic) activity is the management of human interactions with the ecosystem rather than the complex ecosystem itself. The term EAM is also preferable over EM because the latter implies that it is possible to control and manage an entire ecosystem.' ${ }^{1}$ Despite the quasi-official definition of EAM most of the discourse and practice in the United States uses the term ecosystem-based management (EBM) to describe the suite of approaches.

This chapter examines the historical, philosophical and scientific context out of which comes the current discourse in the United States about EBM. It examines the legal basis for Евм in the United States seeking any mandates or legislative direction to require such a policy be implemented. This is followed by description of four, what I term, approaches to implementation of EBM. We start with a review of the single sector approach which is being taken in fisheries management to evolve ecosystem-based fisheries management (ЕBFM). Second, the integrated ecosystem assessment (IEA) approach, which posits integrated scientific support for EBM is reviewed. It has been implemented on a patchwork basis. Third, marine spatial planning (MSP) is assessed as an approach that is being implemented as part of a Presidential Executive

1 C Barnes, L Bozzi and K McFadden in E Crum and J Mechling (eds), Exploring an Ecosystem Approach to Management: A Review of the Pertinent Literature (National Oceanic and Atmospheric Administration 2012).

(C) DAVID FLUHARTY, 2019 | DOI:10.1163/9789004389984_013

This is an open access chapter distributed under the terms of the prevailing CC-BY-NC License at the time of publication. 
order establishing a national ocean policy. ${ }^{2}$ Finally, designation of networks of marine protected areas (MPAs) and large marine area designations has been implemented under Presidential Executive orders and Presidential Declarations in order to ensure protection of large ocean areas by placing them essentially off limits to extractive activities in favor of biodiversity preservation. These so-called other approaches are geographically targeted toward and implemented at the regional level - New England, Mid-Atlantic, South Atlantic, Caribbean, Gulf of Mexico, West Coast, Pacific Islands and Alaskan regions.

To the extent that the United States can claim to have an ecosystem approach to management, it is the product of weaving together these multiple strands of implementation. Not surprisingly, to use an analogy, the results so far resemble an abstract weaving rather than a tapestry. An examination of how each of these strands and their ensemble are able to incorporate or adapt to new uses like marine renewable energy reveals interesting insights into how a true ecosystem approach to management might function and demonstrates inherent weaknesses of this multi-strand approach.

\section{Historical, Philosophical and Scientific Context for EBM}

Historically the trajectory of nature conservation and management of marine resources has been somewhat divergent from and has benefitted from the European experience and vice versa. ${ }^{3}$ Explorers like James Perkins Marsh, ${ }^{4}$ Transcendentalist Henry David Thoreau, ${ }^{5}$ naturalists and scientists like Spencer Baird, ${ }^{6}$ James Burroughs, ${ }^{7}$ and Aldo Leopold, ${ }^{8}$ political leaders like Theodore

2 Coastal Zone Management in the United States <https://coast.noaa.gov/czm/about/> accessed March 24, 2018 is another strand that could be examined but it is left out of this analysis because it is not implemented on a regional scale. Similarly, the NOAA Large Marine Ecosystem program explores management in an ecosystem context but is not considered here < www.st.nmfs.noaa.gov/ecosystems/lme/index > accessed 1 October 2018.

3 Robert P McIntosh, The Background of Ecology: Concept and Theory (Reprint, Cambridge University Press 1988); Andrea Wulf, The Invention of Nature: Alexander von Humboldt's New World (Alfred A. Knopf 2015).

4 James Perkins Marsh, Man and Nature: Or, Physical Geography as Modified by Human Action (Third edition, David Lowenthal (ed), The Belknap Press of Harvard University Press 1974); Hans Huth, Nature and the American: Three Centuries of Changing Attitudes (University of Nebraska Press 1957); Roderick Nash, Wilderness and the American Mind (Yale University Press 1967).

5 Henry David Thoreau, Walden (J. Lyndon Shanley (ed), Princeton University Press 2007).

6 Aldo Leopold, The Sand County Almanac, and Sketches from Here and There (Oxford University Press 1949).

7 John Burroughs, The Complete Nature Writings of John Burroughs (WH Wise 1931).

8 Laura Dassow Walls, Henry David Thoreau: A Life (The University of Chicago Press 2017). 
Roosevelt ${ }^{9}$ and Franklin D. Roosevelt ${ }^{10}$ and many others, shaped terrestrial conservation and preservation as populist movements. These ideas and practices spilled over into US ocean management. In recent decades scientific research, particularly relating to ecosystem science, has exploded although suffice it to say full documentation of those contributions is beyond the scope of this paper. ${ }^{11}$ Nevertheless, by way of example of the long-term influence of ecosystem ideas, Spencer Baird, the first Commissioner of the US Fisheries Commission in 1872, initiated marine ecological studies in his first year in office. According to Baird, our understanding of fish '(...) would not be complete without a thorough knowledge of their associates in the sea, especially of such as prey upon them or constitute their food (...).'12 He went on to discuss the role of ocean conditions and other factors in influencing fisheries productivity and the role of fishing.

The main purpose of this mention of the historic antecedents is to demonstrate that there is a rich and complex background for thinking about and making Е вм decisions. Nevertheless, in order to make ecosystem science more relevant in decision-making it is necessary to know more about what people value and how they behave with respect to the marine environment. If we can understand human values and behavior it may be feasible to construct workable incentives to link ecosystem science to policy decisions through law and regulations. However, despite the fact that all ocean activities take place in an ecosystem context, this understanding is not yet reflected in the development of a sustainable, resilient culture of ocean management in the United States. Nor is US society prepared to use ЕВM to assess trade-offs among competing interests and assign priorities. ${ }^{13}$

9 Darrin Lunde, The Naturalist Theodore Roosevelt, A Lifetime of Exploration, and the Triumph of American Natural History (Crown Publishers 2016).

10 Douglas Brinkley, Rightful Heritage: Franklin D. Roosevelt and the Land of America (HarperCollins 2016).

11 Norman L Christensen and others, 'The Report of the Ecological Society of American Committee on the Scientific Basis for Ecosystem Management' (1996) 6:3 Ecological Applications 665; Anna Bramwell, Ecology in the 2oth Century: A History (Yale University Press 1989).

12 WL Hobart, Baird's Legacy: The History and Accomplishments of NOAA's National Marine Fisheries Service, 1871-1996 (Technical Memorandum NMFS F/SPO-18 1995 United States Department of Commerce, National Oceanic and Atmospheric Administration, National Marine Fisheries Service 1995).

13 Jeremy S Collie and others, 'Marine Spatial Planning in Practice' (2013) 177 Estuarine, Coastal and Shelf Science 1. 
While it is tempting to try to define EAM more narrowly, ${ }^{14}$ it must be realized that ocean management is an ongoing process of negotiated uses. One can imagine a continuum bracketed on one end by a previous state where coasts and oceans received little or no use and their condition might be understood as pristine. On the other end of the continuum we increasingly see government actions restricting or prohibiting ocean use to protect and restore marine ecosystems to a more desired state, usually as a consequence of unsustainable use, e.g., wide-spread pollution, overfishing, extinction threats, etc. In between these endpoints the operating space for EAM is large in terms of extractive or other uses that modify the ecosystem yet produce ecosystem services. It is this decision space that is the target of fisheries managers, integrated assessment scientists and marine spatial planners and is where the concepts of EAM are in the process of being developed and implemented. Hereinafter, EAM and EBM are used synonymously because common usage in the United States does not distinguish between these terms.

\section{3}

\section{Legislation for EBM}

This section takes a restrictive view of what constitutes a mandate in legislation as opposed to instructive or permissive language. Much of what is cited as a mandate for EAM is aspirational language or declaration of intent. In order to qualify as a legal mandate for ввм in the United States a distinct federal agency is required to perform certain actions or duties; funds must be appropriated or otherwise authorized to be spent on those actions, there must be a legal basis and mechanism for enforcement, and failure to implement in accordance with regulations is actionable, i.e., citizens and organizations can use this legal mechanism to sue to challenge actions.

Is there a legal mandate for EBM in the United States? The thesis of this chapter is that there is no comprehensive integrated legal mandate for implementing ЕвM or any mechanism to implement it in the US. ${ }^{15}$ This is true at

14 Cecilia Engler, 'Review: Beyond Rhetoric: Navigating the Conceptual Tangle Towards Effective Implementation of the Ecosystem Approach to Oceans Management' (2015) 23 Environmental Review 288.

15 Patrick A Parenteau and others, 'Legal Authorities for Ecosystem-Based Management in US Coastal and Ocean Areas' in Donald C Baur, Tim Eichenberg and Michael Sutton (eds), Ocean and Coastal Law and Policy (American Bar Association 2007); See also Frederick R Anderson, NEPA in the Courts: A Legal Analysis of the National Environmental Policy Act (Johns Hopkins University Press for Resources for the Future 1973); Richard A Liroff, A National Policy for the Environment (Indiana University Press 1976). 
the sectoral level as well as at a comprehensive, integrated national level. Others might argue that legislation suggests intent or requires use of science that provides equal results if followed. ${ }^{16}$ Attempting to resolve this difference of perspective is beyond the scope of this paper. However, the important observation is that the legal discourse encourages the use of ecosystem science in ocean management and the main intent and effect, so far, is to be permissive rather than prohibitive. The composite of all environmental and marine legislation [more than 140 laws] provides substantial basis for ЕВ tion is implemented in a sectoral, fragmented, conflicting and uncoordinated manner. ${ }^{17}$

To illustrate the sweep and content of legislation with significant application to coastal and ocean management in the United States, six major pieces of legislation are reviewed here: The National Environmental Policy Act 1969; the Marine Mammal Protection Act 1972; the Endangered Species Act 1973; the Magnuson-Stevens Fishery Conservation and Management Act 1976; the Marine Protection, Research and Sanctuaries Act 1972 taken together with the American Antiquities Act 1906 and recent designations of Marine National Monument under the latter. ${ }^{18}$ As will become apparent over the course of this chapter, the initiative for protection and management of the oceans by the federal government has shifted from the Congress and its passage of environmental legislation in the late 1960s to mid-1970s, to the federal courts where interpretation of the regulations implementing the law took place during the late-1970s to the early 1990 s. $^{19}$ Since the mid-1990s, the initiative has largely come from the executive branch of government and this remains true to today. ${ }^{20}$ Nevertheless, even if the recent impetus for Евм comes from the

16 Environmental Law Institute, Ocean and Coastal Ecosystem-Based Management: Implementation Handbook (Environmental Law Institute 2009) <https://www.eli.org/sites/ default/files/eli-pubs/d19_03.pdf> accessed 1 October 2018; See also Christy M Foran and others, 'Relating Mandates in the United States for Managing the Ocean to Ecosystem Goods and Services Demonstrates Broad but Varied Coverage' (2016) 3 Frontiers in Marine Science 5 .

17 Christy M Foran and others, 'Relating Mandates in the United States for Managing the Ocean to Ecosystem Goods and Services Demonstrates Broad but Varied Coverage' [2016] Frontiers in Marine Science 3:5; See also Mary Turnipseed and others, 'Legal Bedrock for Rebuilding America's Ocean Ecosystems' (2009) 324 Science 183; LB Crowder and others, 'Resolving Mismatches in US Ocean Governance' (2006) 313 Science 617.

18 The year of first passage for these laws is provided but all references to these laws include the latest versions as amended by Congress.

19 Other laws with potential wide ecosystem effect include the Coastal Zone Management Act 1972, the Outer Continental Shelf Lands Act 1953, Clean Water Act 1972, etc.

20 David Fluharty, 'Recent Developments at the Federal Level in Ocean Policymaking in the United States' (2013) 40 Coastal Management 209. 
executive branch, the machinations of the Congress and the courts cannot be discounted completely.

\subsection{The National Environmental Policy Act 1969}

The National Environmental Policy Act 1969 (NEPA) requires that environmental impact statements be prepared for all major federal actions (permits, projects, funding and management plans). These environmental impact statements (EIS) must identify the environmental impact of the proposed action; adverse impacts that cannot be avoided if the action is implemented; alternatives to the proposed action and possible mitigation measures; relationships between long and short term productivity; any irreversible and irretrievable commitments of resources; and cumulative impacts, including social and economic impacts which also should be assessed. ${ }^{21} \mathrm{NEPA}$ also requires that the best available scientific information be used in making agency actions. ${ }^{22}$ This standard, implemented through NEPA, could be considered a mandate to the extent it is actionable. Nevertheless, the term 'ecosystem' is not found in the text of the law.

Overall, NEPA applies to all federal actions but not to private or commercial actions not requiring federal involvement. Even though it has mechanisms to require that best available scientific information is made available prior to agency decision-making, the agency is not required to choose actions consistent with protecting the ecosystem. Full disclosure of environmental impacts, which arguably includes cumulative impact on the environment, does not necessarily lead to EBM decisions, especially if funding for more expensive alternative actions or mitigation is needed. In this sense NEPA is procedural in scope. In other words, its main focus is whether the EIs has been developed to an acceptable standard. ${ }^{23}$

21 Modified from Sam Kalen, 'Ecology Comes of Age: NEPAs Lost Mandate' (2010) 21 Duke Environmental Law and Policy Forum 113; See also Ronald E. Bass, Albert I Herson and Kenneth M Bogdan, The NEPA Book: A Step-by-Step Guide on How to Comply with the National Environmental Policy Act (Selano Press Books 2001); Patrick A Parenteau, Donald C Baur and Jennifer L Schorr, 'Legal Authorities for Ecosystem-Based Management in US Coastal and Ocean Areas' in Donald C Baur, Tim Eichenberg and Michael Sutton (eds), Ocean and Coastal Law and Policy (American Bar Association 2007).

22 Natalie Lowell and Ryan P Kelly, 'Evaluating Agency Use of "Best Available Science” Under the United States Endangered Species Act' (2016) 196 Biological Conservation 53; See also Ryan P Kelly and others, 'Harnessing DNA to Improve Environmental Management: Genetic Monitoring Can Help Public Agencies Implement Environmental Laws' (2014) 344 Science 1455 .

23 Donald C Baur, Michael L Gosliner and Nina M Young, "The Law of Marine Mammal Conservation' in Donald C Baur, Tim Eichenberg and Michael Sutton (eds), Ocean and Coastal Law and Policy (American Bar Association 2007). 


\subsection{The Marine Mammal Protection Act 1972}

The Marine Mammal Protection Act 1972 (MMPA) is a very strong, protectionoriented legislation that aims to rebuild or maintain marine mammal populations to optimum sustainable populations (OSP). In that sense it is a single species-oriented approach to management, much like fisheries, rather than legislation incorporating broader ecosystem considerations such as multi species management, management of conflicts among marine mammals, etc. The goal of managing all species of marine mammals for their osP can be seen to interfere with management scenarios involving conflicts between two or more marine mammals as a result of predation or competition for prey. Two federal agencies have primary responsibility for management of marine mammals under the Act: the Fish and Wildlife Service in the Department of Interior and the National Marine Fisheries Service within the National Oceanic and Atmospheric Administration (NOAA) within the Department of Commerce, but the Act applies to all federal agency actions. It also preempts management by state and other federal agencies. With specific application to ЕВM, the MMPA does not provide for protection of habitats/ecosystems on which marine mammals rely. Instead the language asserts that 'all marine mammals should be brought to and maintained at the osp level, provided that efforts to do so are consistent with maintaining the overall health and stability of the marine environment.'24 In practice, measures to maintain overall health and stability have not been applied (depite the term ecosystem being used 18 times in the text of the Act) because no habitat management mechanisms are provided under the MMPA. Instead the focus has been on reducing mortalities from direct and indirect takes, including subsistence harvests by indigenous peoples. Looking forward, it appears that many marine mammals are vulnerable to increased sound in the ocean, climate induced changes in ecosystems and bioaccumulation of contaminants from sea water and prey species, because none of these issues are covered in the Act.

\subsection{The Endangered Species Act 1973}

The Endangered Species Act 1973 (ESA) is one of the strictest and most powerful tools for species protection in the United States. ${ }^{25}$ It builds upon the experience gained since passage of the Endangered Species Preservation Act 1966, which permitted land to be purchased for wildlife habitat, and the Endangered Species Conservation Act of 1969, which allowed for preparation of a list of

\footnotetext{
24 Ibid., 481.

25 William Robert Irvin and Michael Bean, 'The Endangered Species Act and Marine Species' in Donald C Baur, Tim Eichenberg and Michael Sutton (eds), Ocean and Coastal Law and Policy (American Bar Association 2007).
} 
animals threatened with extinction. In 1973 the US hosted the international conference to negotiate the Convention on International Trade in Endangered Species of Wild Fauna and Flora (CITES). ${ }^{26}$ Under the ESA 1973, if a species of plant, animal, fish, turtle, or seabird meets the various criteria for threatened or endangered status - usually as a result of activities that impact their population or habitats - a recovery plan must be prepared that, foremost, prohibits further take of the species. In addition, critical habitat must be protected to ensure that the listed species has a suitable environment to allow recovery. Such designations of critical habitat can restrict entry and limit practices that may harm or slow recovery of a species and have the potential to be applied over a large area. In addition, Habitat Conservation Plans can be prepared by land owning and managing entities to indicate how management will take place so as not to harm or slow recovery of a listed species. Often these Habitat Conservation Plans serve to manage habitats for multiple species. ${ }^{27}$

This species by species approach is not Е BM but it can, in many cases, result in broader management of habitats and ecosystems because of its application across multiple agencies, in particular NOAA in Department of Commerce for marine species and the Fish and Wildlife Service in the Department of Interior for terrestrial species and seabirds. ${ }^{28}$ Surprisingly, the term ecosystem appears only once in the preamble to this legislation and nowhere else. ${ }^{29}$ While there is overlap in some aspects of species protections in the MMPA and the ESA the combination of measures requires significant ecosystem level planning as part of federal management plans for fisheries, forests, coasts and other infrastructure. One of the most prominent examples of planning that contributes to ESA listed species recovery is the Puget Sound Partnership, ${ }^{30}$ where endangered

26 <www.fws.gov/endangered/esa-library/pdf/history_ESA.pdf> accessed December 3, 2017.

27 Patrick A Parenteau, Donald C Baur and Jennifer L Schorr 'Legal Authorities for EcosystemBased Management in US Coastal and Ocean Areas' in Donald C Baur, Tim Eichenberg and Michael Sutton (eds), Ocean and Coastal Law and Policy (American Bar Association 2007).

28 Environmental Law Institute, Ocean and Coastal Ecosystem-Based Management: Implementation Handbook (Environmental Law Institute 2009) <www.eli.org/sites/default/ files/eli-pubs/d19_03.pdf> accessed 1 October 2018.

29 George Miller, 'Ecosystem Management: Improving the Endangered Species Act' (1996) 6 Ecological Applications 715 .

30 Puget Sound Partnership, 'The 2016 Action Agenda for Puget Sound: Comprehensive Plan' $<$ www.psp.wa.gov/action-agenda-document.php > accessed 1 October 2018; See also Puget Sound Partnership, 'The 2016 Action Agenda for Puget Sound: Implementation Plan' <www.psp.wa.gov/action-agenda-document.php> accessed 1 October 2018. 
salmon recovery and endangered orca recovery are drivers and are also inextricably linked. ${ }^{31}$

\subsection{The Magnuson-Stevens Fishery Conservation and Management Act 1976}

The Magnuson-Stevens Fishery Conservation and Management Act 1976 (MSA as it is now known), establishes a management regime for fisheries in federal waters (3-200 nautical miles) offshore of the US aimed at preventing overfishing, rebuilding overfished stocks, ensuring conservation and realizing the full potential of national fisheries resources. ${ }^{32}$ While the core elements apply across all waters of the US, the MSA takes a unique regional approach to management of marine ecosystems. Eight regional fishery management councils are established under the Act. Their members are appointed by the Secretary of Commerce. Decisions of the Councils are advisory to the National Marine Fisheries Service. As one of the principal anthropogenic change drivers in the oceans, fisheries are highly dependent on the marine ecosystem but may also degrade the ecosystem if not managed sustainably. ${ }^{33}$ Early results in US management of its Exclusive Economic Zone fisheries showed very mixed results. Some of these related to habitat concerns and others to overfishing. The focus of the MSA is on species harvested in the fisheries but not exclusively. Fisheries independent surveys sample the full range of biota in addition to the target species and these provide one of the most synoptic monitoring programs of marine biodiversity.

With respect to the ecosystem, the 1996 MSA reauthorization called for a report to Congress on the use of ecosystem principles in US fisheries management. ${ }^{34}$ In 1996 Congress also required the designation of what was defined as Essential Fish Habitat and Habitat Areas of Particular Concern through a short 18 month process to amend each fishery management plan

31 Jameal F Samhouri and others, 'Using Existing Scientific Capacity to Set Targets for Ecosystem-Based Management: A Puget Sound Case Study' (2011) 35 Marine Policy 508.

32 Christy M Foran and others, 'Relating Mandates in the United States for Managing the Ocean to Ecosystem Goods and Services Demonstrates Broad but Varied Coverage' (2016) 3 Frontiers in Marine Science 5 .

33 Alida Bundy and others, 'Strong Fisheries Management and Governance Positively Impact Ecosystem Status' (2017) 18 Fish and Fisheries 412.

34 National Marine Fishery Service, Ecosystem Principles Advisory Panel 'Ecosystem-Based Fisheries Management: A Report to Congress by the Ecosystem Principles Advisory Panel' (National Marine Fisheries Service. National Oceanic and Atmospheric Administration 1999). 
as well as other measures to limit bycatch. ${ }^{35}$ In the 2006 MSA reauthorization Congress added language to the effect to encourage fishery management councils to develop ecosystem-based management approaches, but it did not require that Councils develop Fisheries Ecosystem Plans or other measures. Current proposals (2017) for MSA reauthorization do not add ecosystem-based management language.

With or without explicit mandates or other directions to implement Евм in regional fisheries management there is significant progress being made. However, this progress is not the result of legislative mandates, but rather of initiatives undertaken at the executive level. [See below]. As will become apparent, there are multiple laws and regulations under which the National Marine Fisheries Service manages fisheries. This ensures a broad consideration of the ecosystem but does not constitute an integrated or comprehensive approach to EBM.

\subsection{The Marine Protection, Research and Sanctuaries Act 1972 and the American Antiquities Act 1906}

The Marine Protection, Research and Sanctuaries Act 1972 (MPRSA) and the American Antiquities Act 1906 (AAA) may seem an odd pairing but they each respond fundamentally to a perception that fisheries management and other approaches to managing the ocean are failing or are inadequate to the task of sustaining biologically diverse ocean ecosystems. As a result of these perceived failings, it has been accepted that there is a need to establish marine protected areas where the management objective is to limit or prohibit certain activities in order to allow the ocean to recover. ${ }^{36}$ The MPRSA was originally a special management ocean designation aimed at managing multiple uses in an area for conservation purposes. The National Marine Sanctuary program in NOAA was expected to coordinate with other entities to achieve its ocean conservation purposes, given that it has no separate authority to control shipping, fishing, etc. ${ }^{37}$ In recent years, the concept that National Marine Sanctuaries (NMS) are places of refuge from exploitation has taken hold in public perception, and Sanctuary Management Plans are becoming increasingly restrictive. After a lengthy hiatus (2000-2014) the process of nominating new National Marine

35 Andrew Rosenberg and others, 'Ecosystem Approaches to Fishery Management Through Essential Fish Habitat' (2000) 66 Bulletin of Marine Science 535 .

36 Jane Lubchenco and others, 'Plugging a Hole in the Ocean: The Emerging Science of Marine Reserves' (2003) 13(1) Ecological Applications Supplement S3.

37 Kim Diana Connolly, Jennifer L Schorr and Darren Misenko, 'Marine Protected Areas' in Donald C Baur, Tim Eichenberg and Michael Sutton (eds), Ocean and Coastal Law and Policy (American Bar Association 2007). 
Sanctuaries has been implemented and new areas have been proposed to be added to the program.

It should be noted that NMS designation under the MPRSA is not the only tool that federal agencies can invoke to protect nationally important areas. Other options include national parks, national wildlife refuges, wilderness designations, fishery management closures, and national recreation areas. However, National Marine Sanctuaries designated under the MPRSA are afforded certain protections from offshore oil and gas development, ocean dumping, and other measures specific to each designation. NMs must meet other planning and management requirements, thus making this form of designation farreaching and more effective.

In recent years, as a result of Presidential declarations under the AAA, ${ }^{38}$ very large areas have been designated as Marine National Monuments. The areas so proclaimed have mostly been located in unpopulated and unmanaged ocean areas in the remote Pacific Islands where few human uses occur. These declarations have been hailed as major victories for conservation by environmental non-governmental organizations, but they have been objected to by some fisheries organizations whose members rely on harvests of highly migratory species in the open Pacific Ocean. The fundamental problem from a legal and governance perspective is that the AAA 1906 allows Presidents the authority to protect areas that hold high value cultural artifacts, usually Native American artifacts. It is not completely clear that Presidents can designate marine areas under the AAA. Especially with respect to marine areas, it is not clear that Presidents have the authority to use the AAA offshore. Further, whether on land or at sea the AAA does not provide processes or resources for management direction or planning, and there are no additional funds allocated to plan for management, or to monitor status, or to enforce against threats. Protections under the AAA 2006 simply designate an area as a Marine National Monument. As there are no associated provisions for management of the areas the question arises as to why bother with such designations. Indeed, the MNM established in federal waters off New England has attracted significant criticism for ignoring public comments provided through established processes (such as the regional fishery management council) despite the designation imposing significant costs on some fishery sectors through closure of ocean areas. Further, these protections are not solely for cultural properties. Instead the focus is on marine biodiversity.

38 Mark Stephen Squillace and others, 'Presidents Lack the Authority to Abolish or Diminish National Monuments' (2017) 103 Virginia Law Review Online 55. 
Management orientations for National Marine Sanctuaries and, by their very nature, Marine National Monuments, tend to fall into the end of the continuum of prohibited extractive use with the intent to maintain or restore pristine habitats.

\subsection{Summary}

As has been demonstrated, legislation with respect to Евм is scarce in the US. Aside from the responsibility to reauthorize funding for fisheries, marine mammals, endangered species and marine protected areas, Congress has been willing, on a regular basis, to endorse ЕВм but not to mandate that such an approach be applied in management. One can argue that this approach is prudent in that the critical wording of a statute for EBM might be difficult to craft as long as there is no agreed upon definition of Евм or a goal for management. Others might consider that requiring federal agencies to utilize Евм in fisheries or sanctuary management plans would be useful, if not too prescriptive. It is possible and optimistic to observe that, through NEPA, Congress has required that agencies use best available science and information in making management decisions and that reliance on this science is arguably Eвм. ${ }^{39}$ Similarly, if one asks agency personnel to evaluate whether they use ввм best practices and principles in their program implementation the results appear to be mixed but lean in favor of management programs being more ecosystembased than not. ${ }^{40}$

\section{$4 \quad$ Executive Branch Initiatives}

The transition from environmental legislation and judicial interpretations to action at the executive branch level occurred primarily in the 1990s. Apart from the work done by academic scientists, there was sufficient interest in Congress to request two studies concerning ecosystem management through the Congressional Research Service. ${ }^{41}$ At the same time, in response to Vice President

39 Norman L Christensen and others, 'The Report of the Ecological Society of American Committee on the Scientific Basis for Ecosystem Management' (1996) 6:3 Ecological Applications 665 .

40 Andrea Dell'Apa and others, 'The Status of Marine and Coastal Ecosystem-Based Management Among the Networks of U.S. Federal Programs' (2015) 6o Marine Policy 249.

41 Eugene H Buck, 'Congressional Research Service Report for Congress: Marine Ecosystem Management' (Congressional Research Service 1993); See also Wayne Morrissey, Jeffry Zinn and Lynne Corn, 'Ecosystem Management in the Federal Agencies' (Congressional Research Service 1994). 
Gore's National Performance Review, the incoming Clinton administration convened an interagency Task Force of 15 executive agencies that issued a report on The Ecosystem Approach: Healthy Ecosystems and Sustainable Economies in $1995 .{ }^{42}$ The focus of this effort was on federal agency coordination, partnerships with non-federal stakeholders and communication between the federal agencies and the public. This report led to a Memorandum of Understanding to Foster the Ecosystem Approach among federal agencies. ${ }^{43}$ Despite this high level of engagement, however, it is not clear how this report and memorandum actually influenced agency practice ${ }^{44}$ and not much effort was made to distinguish marine and terrestrial EBM differences. ${ }^{45}$ Indeed, there was very strong Congressional push back to these policy declarations and any actions proposed to be taken to implement them. ${ }^{46}$

Nevertheless, since the late 199os Executive Branch initiatives have emerged for Ecosystem-Based Fisheries Management (евғм), Integrated Ecosystem Assessments (IEAs), Coastal and Marine Spatial Planning (CMSP) and Large Marine Protected Areas (LMPA). The origins, key concepts and implementation of each of these initiatives are reviewed below as well as their current status.

\subsection{Ecosystem-Based Fishery Management}

With respect to fisheries, in its reauthorization of the MSA 1996 (Section 406$)^{47}$ Congress required the National Marine Fisheries Service to convene a panel

42 National Technical Information Service, 'The Ecosystem Approach: Healthy Ecosystems and Sustainable Economies, Volume 1' (NTIS 1995). Two other volumes of the report focus on implementation issues and case studies respectively.

43 Office of Environment and Planning, Executive Office of the President, 'Memorandum of Understanding to Foster the Ecosystem Approach' (The White House 1995) <https://www .fhwa.dot.gov/legsregs/directives/policy/memoofun.htm> accessed December 10, 2017.

44 M Boyce and A Haney, Ecosystem Management: Applications for Sustainable Forest and Resources (Yale University Press 1996); See also Allan K Fitzsimmons, Federal Ecosystem Management: A 'Train Wreck' in the Making (Cato Institute Policy Analysis No. 217, Cato Institute 1994) <www.cato.org/publications/policy-analysis/federal-ecosystem -management-train-wreck-making> accessed December 10, 2017.

45 Roger B Griffis and Katharine W Kimball, 'Ecosystem Approaches to Coastal and Ocean Stewardship' (1996) 6 Ecological Applications 708.

46 Wayne A Morrissey, 'Science Policy and Federal Ecosystem-Based Management' (1996) 6 Ecological Applications 717; See also Frederick H Wagner, 'Whatever Happened to the National Biological Survey?' (1999) 49 BioScience 219.

47 National Marine Fisheries Service, Ecosystem Principles Advisory Panel 'Report of the Ecosystem Principles Advisory Panel to Congress' (National Marine Fisheries Service. National Oceanic and Atmospheric Administration 1999) requires the Panel to report, 'within two years after the date of enactment of this Act, the Secretary [of Commerce] 
to prepare a report on the application of ecosystem principles in US fisheries conservation and management. Based on its members' experience and review of ecosystem literature the report from the Ecosystem Principles Advisory Panel suggested that the following Principles, Goals and Policies embody a framework for ecosystem-based fisheries management (EBFM).

In order to report on the use of ecosystem principles in US fisheries management the Panel had to define what it considered to be ecosystem principles for fisheries management. The Panel defined eight principles (NMFS 1999): 1) the ability to predict ecosystem behavior is limited; 2) ecosystems have real thresholds and limits which, when exceeded, can effect major system restructuring; 3) once thresholds and limits have been exceeded, changes can be irreversible; 4) diversity is important to ecosystem function; 5) multiple scales interact within and among ecosystems; 6 ) components of ecosystems are linked; 7) ecosystem boundaries are open; and 8) ecosystems change with time. To be clear, this was a consensus-based definition of principle with the recognition that there were many ways that such principles could be stated for fishery management. ${ }^{48}$

Next the Panel had to come to agreement on goals which it did by defining the goal of EBFM to be to 'maintain ecosystem health and sustainability. 49

shall submit to the Congress a completed report of the panel established under this section, which shall include -

(1) an analysis of the extent to which ecosystem principles are being applied in fishery conservation and management activities, including research activities:

(2) proposed actions by the Secretary and by the Congress that should be undertaken to expand the application of ecosystem principles in fishery conservation and management; and

(3) such other information as may be appropriate.'

48 Jason S Link, 'What Does Ecosystem-Based Fisheries Management Mean?' (2002) 27:4 Fisheries 18; See also JS Link, 'Ecological Consideration in Fisheries Management: When Does it Matter?' (2002) 27:4 Fisheries 10; K Arkema, S Abramson and B Dewsbury, 'Marine Ecosystem Management: From Characterization to Implementation' (2006) 4 Frontiers in Ecology and Management 525; Jake Rice, 'Managing Fisheries Well: Delivering the Promises of and Ecosystem Approach' (2011) 12 Fish and Fisheries 209.

49 National Marine Fisheries Service, Ecosystem Principles Advisory Panel 'Report of the Ecosystem Principles Advisory Panel to Congress' (National Marine Fisheries Service. National Oceanic and Atmospheric Administration 1999). 
The kinds of policies that the Panel considered to be consistent with the principles and goals were identified as: 1) change the burden of proof; 2) apply the precautionary approach; 3) purchase 'insurance' against unforeseen, adverse ecosystem impacts; 4) learn from management experiences; 5) make local incentives compatible with global goals; and 6) promote participation, fairness and equity in policy and management. ${ }^{50}$

The most important parts of the Panel report are the recommendations for how to implement an EBFM approach in existing fisheries management under the MSA. The chief recommendation was to prepare a Fisheries Ecosystem Plan (FEP) for each marine fisheries management region to serve as an umbrella document bringing an ecosystem focus to fishery management regulatory actions. The FEP would be developed regionally to take advantage of unique fisheries circumstances and regional priorities. Each FEP would be expected to: 1) delineate the geographic extent of the ecosystem(s) that occur(s) within Council authority, including characterization of the biological, chemical and physical dynamics of those ecosystems, and 'zone' the area for alternative uses; 2) develop a conceptual model of the food web; 3) describe the habitat needs of different life history stages for all plants and animals that represent the 'significant food web' and how they are considered in conservation and management measures; 4) calculate total removals - including incidental mortality and show how they relate to standing biomass, production, optimum yields, natural mortality and trophic structure; 5) assess how uncertainty is characterized and what kind of buffers against uncertainty are included in conservation and management actions; 6) develop indices of ecosystem health as targets for management; 7) describe available long-term monitoring data and how they are used; and 8) assess the ecological, human, and institutional elements of the ecosystem which most significantly affect fisheries, and are outside Council/ Department of Commerce (DOC) authority. ${ }^{51}$ Included should be a strategy to address those influences in order to achieve both Fishery Management Plan and FEP objectives. ${ }^{52}$

Despite this initial flurry of activity by NMFS to develop EBFM, a change of administration and a less supportive Congress conspired to limit

50 Ibid.

51 Ibid.

52 David Fluharty and Ned Cyr, 'Implementing Ecosystem-Based Management of Fisheries in the Context of US Regional Fisheries Management: Recommendations of the NMFS Ecosystem Principles Advisory Panel' (2001) 42 CalCOFI Reports 66. 
implementation of the Panel's recommendations. ${ }^{53}$ Efforts continued to explore what EBFM might mean both within $\mathrm{NMFS}^{54}$ and in academia. ${ }^{55}$

In 2014 a review of implementation of ЕBFM performed by the Ecosystem Sciences and Management Working Group of NOAA's Science Advisory Board and drawing from the recommendations of the 1999 NMFS Ecosystem Principles Report to Congress showed significant progress toward EBFM was being made in most fishery management regions. ${ }^{56} \mathrm{NMFS}$ also performed a benchmarking of FEPS. ${ }^{57}$ This led to NMFS developing two documents to guide further implementation of ЕВFм i.e., a statement of policy and a roadmap. ${ }^{58}$

53 D Witherell, C Pautzke and D Fluharty, 'An Ecosystem Based Approach for Alaska Groundfish Fisheries' (2000) 57 ICES Journal of Marine Sciences 771; National Oceanic and Atmospheric Administration, 'Chesapeake Bay Fisheries Ecosystem Plan' (NOAA Chesapeake Bay Office 2004).

54 SA Murawski, 'Ten Myths Concerning Ecosystem Approaches to Marine Resource Management' (2007) 31 Marine Policy 681; See also National Marine Fisheries Service, NOAA Fisheries, 'Requirements for an Ecosystem Approach to Management of Living Marine Resources' (DOC/NOAA/NMFS 2004); National Marine Fisheries Service, 'The State of Science to Support an Ecosystem Approach to Regional Fishery Management: Pursuant to the Magnuson-Stevens Fishery Conservation and Management Act, Section 406(f) Report to Congress' (nOAA Technical Memo, NMFs F/SPO-96 nOAA, US Department of Commerce 2009); Jason S Link, Ecosystem-Based Fisheries Management: Confronting Tradeoffs (Cambridge University Press 2010).

55 Ellen Pikitch and others, 'Ecosystem-Based Fisheries Management' (2004) 305 Science 346; See also Mary Ruckelshaus and others, 'Marine Ecosystem-based Management in Practice: Scientific and Governance Challenges' (2008) 58:1 BioScience 53; DJ Walters and SJD Martell, Fisheries Ecology and Management (Princeton University Press 2004); TJ Pitcher and others, 'An Evaluation of Progress in Implementing Ecosystem-Based Management of Fisheries in 33 Countries' (2009) 33 Marine Policy 223; Heather Tallis and others, 'The Many Faces of Ecosystem-Based Management: Making the Process Work Today in Real Places' (2010) 34 Marine Policy 340; Andrea Belgano and Charles W Fowler, Ecosystem-Based Management for Marine Fishes: An Evolving Perspective (Cambridge University Press 2011); Jake Rice, 'Managing Fisheries Well: Delivering the Promises of an Ecosystem Approach' (2011) 12 Fish and Fisheries 209.

56 Ecosystem Sciences and Management Working Group, NOAA Science Advisory Board 'Exploration of Ecosystem-Based Fishery Management in the United States' (National Oceanic and Atmospheric Administration, Science Advisory Board 2014) <ftp://ftp.oar .noaa.gov/SAB/sab/Reports/SAB\%2oEBFM\%2oReport\%t20\%toNOAA_July\%202014_ Final.pdf> accessed December 10, 2017; See also NOAA Response $(2015)<\mathrm{ftp}$ ://ftp.oar .noaa.gov/SAB/sab/Meetings/2015/August/NOAA_Resp_EBFM_2015_Final\%20(2).pdf> accessed 1 October 2018.

57 Erin B Wilkinson and Karen Abrams, 'Benchmarking the 1999 EPAP Recommendations with Existing Fishery Ecosystem Plans' UsDoc/NOAA/NMFS NOAA Technical Memorandum NMFS-OSF-5 (2015).

58 National Marine Fisheries Service, 'Ecosystem-Based Fisheries Management Policy' NMFS Policy Directive 01-120 May 23, 2016 <www.fisheries.noaa.gov/resource/document/ 
Interest by the Pew Foundation's Lenfest Oceans Program produced additional suggestions for contents of FEPs that updated the recommendations of the 1999 Panel. ${ }^{59}$ Actions taken have improved stock assessments to include environmental variables, protected habitats, reduced bycatch, taken into account the role of forage fish in ecosystems, etc. Despite progress made toward implementing ЕBFM, critics point to the fact that the fish-centric focus does not encompass all uses and users of the sea and that a broader approach to marine management is desired.

\subsection{Ecosystem-Based Management}

Congress passed the Oceans Act of 2000 which established a US Commission on Ocean Policy (USCOP) to make high level recommendations on ocean management in a report to Congress. In 2004 the USCOP made its report calling for a doubling of funding for ocean management, more coordinated approaches to management among federal agencies, and Ecosystem-Based Management through regional ocean councils. ${ }^{60}$ Similar recommendations were arrived at in 2003 by a high level group convened by the Pew Trusts, and an environmental non-governmental organization known as the Pew Oceans Commission (POC). ${ }^{61}$ While the UsCOP recommended the formation of a National Oceans Council in the Executive Office of the President to coordinate among federal agencies to implement a National Ocean Policy Framework, the POC recommended that Congress pass a National Ocean Policy Act to include a new national oceans agency and a permanent national oceans council. President Bush rolled out a US Ocean Action Plan $(2004)^{62}$ in response to the USCOP report and by Executive Order 13366 (December 17, 2004) established

ecosystem-based-fisheries-management-policy> accessed 1 October 2018; See also National Marine Fisheries Service, 'NOAA Fisheries Ecosystem-Based Fisheries Management Road Map' NMFS Instruction 01-120-01 November 2016 < https://www.st.nmfs.noaa .gov/Assets/ecosystems/ebfm/EBFM_Road_Map_final.pdf> accessed 1 October 2018.

Lenfest Ocean Program, 'Building Effective Fishery Ecosystem Plans: Report from the Lenfest Fishery Ecosystem Task Force' (2016) <https://www.lenfestocean.org/news-and -publications/published-paper/building-effective-fishery-ecosystem-plans $>$ accessed 1 October 2018.

6o US Commission on Ocean Policy, An Ocean Blueprint for the 21st Century: Final Report (2004) available at <https://govinfo.library.unt.edu/oceancommission/documents/full_ color_rpt/ooo_ocean_full_report.pdf> accessed December 11, 2017.

61 Pew Oceans Commission, America's Living Oceans: Charting a Course for Sea Change (2003) available at <https://www.pewtrusts.org/ /media/assets/2003/06/o2/poc summary.pdf $>$ accessed 1 October 2018.

62 Office of the President, 'US Ocean Action Plan: The Bush Administration's Response to the US Commission on Ocean Policy' (2004) <www.cmts.gov/downloads/US_ocean_ action_plan.pdf> accessed December 12, 2017. 
a Cabinet-level National Ocean Council (NOC) and ancillary bodies, led by the Council on Environmental Quality to advise him on policies related to the oceans. While this all seems to indicate decisive action, the overall effect is aptly summarized as, '[A]lthough the Action Plan took steps towards fulfilling the UsCop's recommendations (...) it made only very limited references to ecosystem issues and did not require any concrete or specific steps toward Евм.'63

\subsection{Integrated Ecosystem Assessment}

In light of the limited action by the Bush Administration to implement policy recommendations by the USCOP, the National Oceanic and Atmospheric Administration (NOAA) (a government agency with primary management responsibilities for weather and climate forecasting, marine fisheries management, coastal zone management, ocean surveys, marine scientific research and endangered species management) considered what it might do to assist in developing a more coherent ecosystem-based management support. ${ }^{64}$ Acting through its Science Advisory Board, in 2004 NOAA established a small working group under the rubric of the External Ecosystem Task Team (EETT) to deliberate on the issue and to make recommendations on how NOAA could further engage in ЕВM. The ЕЕTT reported back to NOAA calling for it to coordinate its assets at the regional level to develop Integrated Ecosystem Assessments (IEA) as a support tool needed to consolidate ecosystem-level information updated on a regular interval for use by agencies in coastal and marine management. ${ }^{65}$ The Report calls upon NOAA to work with its partners - tribes, local and state government agencies as well as other federal agencies to assemble ecosystem knowledge that would provide authoritative scientific understanding of status and trends in regional marine ecosystems in order to support planning and management.

Among the recommendations of the EETT were that NOAA should develop a plan for ecosystem science needs and use the tool of IEAs as a framework for

63 Donald C Baur, Patrick A Parenteau and Georgia Hancock Snusz, 'Legal Authorities for Ecosystem-Based Management in Coastal and Ocean Areas' in Donald C Baur and others (eds), Ocean and Coastal Law and Policy (second edition, American Bar Association 2015).

64 National Oceanic and Atmospheric Administration, 'New Priorities for the 21st Century - NOAA's Strategic Plan: Updated for FY 2006-FY 2011' (US Department of Commerce NOAA 2005).

65 External Ecosystem Task Team (EETT), NOAA Science Advisory Board, 'Evolving an Ecosystem Approach to Science and Management Throughout NOAA and its Partners: Final Report' (NOAA, SAB 2006) <httpp//sab.noaa.gov/sites/SAB/Reports/EETT/eERRT\%20 -\%2oFinal\%2oReport\%2oto\%2oNOAA\%2oOct\%2006.pdf> accessed 1 October 2018. 
coordination. Building on the existing capacities for sustained ocean observations, analysis of status and trends in ocean in terms of space and time, and integration and forecasting, the E ETT asserted that additional capabilities were needed in the form of 1 ) new modeling and forecasting tools; 2) social science methods for linking ecosystem science with governance; 3) understanding behavior of society in response to changing ecosystem components; 4) ecosystem structure and function; 5) technical analyses for things like contaminants and toxics; 6) biodiversity and taxonomy using eDNA; 7) data archiving and integration; and 8) ecosystem impacts of specific human activities. ${ }^{66}$

NOAA leadership responded by setting up regional teams to implement the recommendations and developing a science plan ${ }^{67}$ and technical guidance for these teams. ${ }^{68}$ The focus of the technical guidance was on developing an iterative process for construction and review of IEAs starting with 1) scoping of key issues and stressors; 2) assessment of state, indicators and trends of ecosystem condition relative to targets; 3) assessment of environmental, economic and social causes and consequences of trends; 4 ) forecast/evaluation of ecosystem conditions under a range of management actions and policies; 5) evaluation of management effectiveness for emerging ecosystem issues; and 6) identification of knowledge or data gaps.

In spite of efforts to bring attention to NOAA's efforts and to engage with a broader set of interests and agencies ${ }^{69}$ broader events conspired to limit the full implementation of the IEA approach by NOAA. First, the downturn in the economy late in the first decade of the 20oos resulted in budget cuts in essential programs and left little funding to support regional IEA preparation in all regional ecosystems. Second, the election of a new President and change of administration took EBM efforts in a new direction. (See Coastal and Marine Spatial Planning section below).

Still, dedicated NOAA IEA regional teams persist in their efforts to develop and demonstrate IEAs under the auspices of and in partnership with the California Current Ecosystem, Gulf of Mexico, Northeast US, Alaska and

\footnotetext{
66 Ibid.

67 SA Murawski and GC Matlock (eds), 'Ecosystem Science Capabilities Required to Support NOAA's Mission in the Year 2020' (NOAA Technical Memorandum NMFS-F/sPO-74 US Department of Commerce (2006).

68 PS Levin and others, 'Integrated Ecosystem Assessments' (nOAA Technical Memorandum NMFS-NWFSC-92 U.S. Department of Commerce 2008).

69 Phillip S Levin and others, 'Integrated Ecosystem Assessments: Developing the Scientific Basis for Ecosystem-Based Management of the Ocean' (2009) 7:1 Public Library of Science Biology; See also Yvonne L deReynier, Phillip S Levin and Noriko L Shoji, 'Bringing Stakeholders, Scientists and Managers Together Through an Integrated Ecosystem Assessment Process' (2010) 34 Marine Policy 534.
} 
the Pacific Islands. ${ }^{70}$ For example, the NOAA IEA regional team has partnered with the West Coast Governors' Alliance since in 2006. ${ }^{71}$ Gradual progress has been made to develop six IEAs and to consolidate them into a West Coast IEA that has been used by the Pacific Fishery Management Council in its FE P development process and by the Channel Islands National Marine Sanctuary in its 5 -year condition reports. ${ }^{72}$ Similar efforts to reach out to marine sanctuaries and fishery management councils are taking place. The most recent developments have been in the Northeast Region and the Mid-Atlantic region where NOAA IEA teams have been instrumental in providing the scientific basis for coastal and marine spatial planning. ${ }^{73}$ In a certain sense, regional IEAs have served as test beds for developing many of the technical competencies for application in IEAs even if they have not succeeded in being comprehensively and systematically used as a tool in all regions. ${ }^{74}$

70 NOAA Fisheries, Office of Science and Technology, 'NOAA's Integrated Ecosystem Assessment Program (IEA): Ecosystem Science Review' (2016) <www.st.nmfs.noaa.gov/Assets/ science_program/ecosystem-program-review/IEA/EcosystemScienceReviewOST_IEA_ Final.pdf> accessed 1 October 2018; See also Phillip S. Levin and others, 'Guidance for Implementation of Integrated Ecosystem Assessments: A US Perspective' (2013) 71 ICES Journal of Marine Science 1198; Jameal F Samhouri and others, 'Lessons Learned from Developing Integrated Ecosystem Assessments to Inform Marine Ecosystem-Based Management in the USA' (2014) 71:5 ICES Journal of Marine Science 1205; Michael A Reiter and others, 'An Integrated Framework for Informing Coastal and Marine Ecosystem Management Decisions' (2013) 15:1 Journal of Environmental Assessment Policy and Management.

71 West Coast Governor's Agreement on Ocean Health 'Integrated Ecosystem Assessment (IEA) Action Coordination Team, Final Work Plan' (2012) <www.westcoastoceans.org/ media/IEAworkplanfinalo4242012.pdf $>$ accessed 1 October 2018.

72 Chris Harvey and others, 'NOAA's Integrated Ecosystem Assessment Program: California Current Region 3-YearWork Plan (FY2016-FY2018)' <www.integratedecosystemassessment .noaa.gov/Assets/iea/gulf/documents/regional-work-plans/NOAA-IEA-Work-Plan -CCIEA.pdf> accessed 1 October 2018.

73 NOAA Fisheries, Office of Science and Technology, 'NOAA's Integrated Ecosystem Assessment Program (IEA): Ecosystem Science Review' (2016) <www.st.nmfs.noaa.gov/Assets/ science_program/ecosystem-program-review/IEA/EcosystemScienceReviewOST_IEA_ Final.pdf $>$ accessed 1 October 2018.

74 For example in Puget Sound, Washington, USA, IEAs have been used to test development of targets for ecosystem-based management and for indicators of human well-being in restoration efforts. See Jameal F Samhouri and others, 'Using Existing Scientific Capacity to Set Targets for Ecosystem-Based Management: A Puget Sound Case Study' (2011) 35 Marine Policy 508; See also Kelly Biedenweg, Haley Harguth and Kari Stiles, 'The Science and Politics of Human Well-being: A Case Study in Cocreating Indicators for Puget Sound Restoration' (2017) 22:3 Ecology and Society. 


\subsection{Coastal and Marine Spatial Planning}

The election of President Barack Obama signaled the start of a progressive era for environmental protection of the oceans. Previous administrations had experimented with legislation, EBFM and IEAs to implement recommendations of the USCOP and the POC. While progress was being made in the fisheries management context, IEAs were languishing from lack of budgetary support and general lack of awareness of their utility. ${ }^{75}$ National level environmental non-governmental organizations were emboldened by the willingness of the new administration to consider E BM. It should be said that these organizations were disappointed by the progress they had made in developing networks of marine protected areas and sought a way to resurrect MPAs as part of a broader program where MPAs would be effected as a result of ocean planning. Strategically, it was easier to ask for a portion of the national ocean management area to be set aside for biodiversity protection as part of a larger spatial planning exercise than to achieve MPA designation independently.

For an administration eager to implement the recommendations of the USCOP with respect to EBM, and to generate a national ocean policy, the initial days of the new administration were important. First President Obama issued a policy memorandum to all heads of federal agencies calling for them to assist in the development of a national ocean policy. ${ }^{76}$ With this memorandum, the President convened an Interagency Ocean Policy Task Force (OPTF) in 2009 to report to him in 180 days with recommendations for a Framework for a National Ocean Policy. The Task Force was charged '(...) to develop, with appropriate public input, a recommended framework for effective coastal and marine spatial planning. The framework should be a comprehensive, integrated, ecosystem-based approach that addresses conservation, economic activity, user conflict, and sustainable use of ocean, coastal and Great Lakes resources consistent with international law (...).' This OPTF temporarily suspended the Bush administration's Committee on Ocean Policy established by Executive Order 13366.

75 Environmental Law Institute, Marine Spatial Planning in US Waters: An Assessment and Analysis of Existing Legal Mechanisms, Anticipated Barriers, and Future Opportunities (Environmental Law Institute for Ocean Conservancy 2009).

76 The White House, Office of the Press Secretary 'Memorandum for the Heads of Executive Departments and Agencies, National Policy of the Oceans, Our Coasts, and the Great Lakes' June 12, 2009 <https://obamawhitehouse.archives.gov/administration/eop/ oceans/policy> accessed December 16, 2017. 
Following receipt of the OPTF report, ${ }^{77}$ President Obama issued an Executive Order 13547 (Sec. 10 revoking EO 13366) entitled Stewardship of the Oceans, Our Coasts, and the Great Lakes, July 19, 2010. The Executive Order establishes a National Ocean Council that mirrors the composition of the earlier Bush appointed group and other ancillary bodies including a Governance Coordinating Committee (Sec. 7), and Regional Advisory Committees (Sec. 8). It defines the central recommendation for coastal and marine spatial planning (CMSP) to mean, '(...) a comprehensive, adaptive, integrated, ecosystembased, and transparent spatial planning process, based on sound science, for analyzing current and anticipated uses of the ocean, coastal and Great Lakes areas. ${ }^{78}$ The regional coastal and marine spatial plans are to be comprehensive, regional, integrated, resilient, ecosystem-based and to make use of best available science and information. However, to one of the Executive Order provisions (Sec. 9 (d)) a sobering note is added. 'This order is not intended to, and does not, create any right or benefit, substantive or procedural, enforceable at law or in equity by any party against the United Stated, its departments, agencies, or entities, its officers, employees, or agents, or any other person.' In other words, participation in these regional planning efforts is to be voluntary, employing existing laws and policies and in practical terms highly dependent on extraordinary willingness to cooperate and exceptional cleverness to develop CMSP using existing requirements, many of which are contradictory. Clearly the National Ocean Policy is aspirational in terms of its objectives. Finally, a tight timeline was set for developing regional ocean plans and having them approved by the National Ocean Council and no new fiscal or human resources were made available. Thus, CMSP was very much an unfunded mandate but also one with no separate legal authority other than the leadership the President could provide for under an Executive Order.

Besides the provisions for CMSP, the National Ocean Policy Priority Objectives are: 1) ecosystem based management; 2) inform decisions and improve understanding; 3) better coordination and support for federal, state, tribal, local, and regional management; 4) resiliency and adaptation to climate change and ocean acidification; 5) regional ecosystem protection and restoration;

77 White House Council on Environmental Quality, Final Recommendations of the Interagency Ocean Policy Task Force (Council on Environmental Quality 2010) <https://www .nsf.gov/geo/opp/opp_advisory/briefings/nov2010/optf_finalrecs.pdf $>$ accessed 1 October 2018.

78 The White House, Office of the Press Secretary, Executive Order 13547 Stewardship of the Ocean, Our Coasts, and the Great Lakes, July 19, 2010. Section $3(\mathrm{~b})<\mathrm{https} / / /$ obama whitehouse.archives.gov/the-press-office/executive-order-stewardship-ocean-our -coasts-and-great-lakes > accessed December 16, 2017. 
6) water quality and sustainable practices on land; 7) changing conditions in the Arctic; and 8) ocean, coastal, and Great Lakes observations, mapping and infrastructure.

These all appear to be legitimate objectives for, or parts of, a national ocean policy. However they represent a tall order when only the convening entity, i.e., the Council on Environmental Quality is designated as the lead entity while all other departments and agencies are expected to participate without resolution of conflicting jurisdictions or laws and regulations. ${ }^{79}$ This national ocean policy recognizes the breadth of the ocean policy realm - especially emerging issues - but it ignores existing jurisdictions and responsibilities of sectoral agencies like fisheries, shipping, oil and gas, etc. with their own legislative mandates.

Resistance to implementation of the National Ocean Policy came almost immediately from ocean industries and coastal and ocean users. These groups prevailed on Congress not to fund CMSP. ${ }^{80}$ Enthusiastic support for the NOP came from national environmental advocacy organizations as well as some 'good governance' experts who saw an opportunity to reduce or avoid conflicts by making trade-offs through planning. ${ }^{81}$

As a result of these protests, and only modest support, the NOC labored to develop a National Ocean Policy Implementation Plan ${ }^{82}$ and a Marine Planning Handbook. ${ }^{83}$ These documents are not nearly as prescriptive as the original

79 NOAA Science Advisory Board recognized the need to provide sideboards to the cMsP discussion and requested its Ecosystem Sciences and Management Working Group to review representative marine spatial processes from around the United States where ocean planning was underway, e.g., Massachusetts, New York, and Oregon as well as international experience. The report developed is reflected in Jeremy S Collie and others, 'Marine Spatial Planning in Practice' (2013) 117 Estuarine, Coastal and Shelf Science 1.

8 o Committee on Natural Resources, US House of Representatives, Subcommittee on Water, Power and Oceans Oversight Hearing Implications of President Obama's National Ocean Policy (Serial No. 114-43 May 17, 2016, US Government Printing Office) <https://www.gpo .gov/fdsys/pkg/CHRG-114hhrg20220/pdf/CHRG-114hhrg20220.pdf> accessed December $17,2017$.

81 Ashley L Erickson, Margaret R Caldwell and J Zackary Koehm, 'Smart Ocean Planning: Drivers, Enabling Conditions, and Global Examples' in Donald C Baur and others (eds), Ocean and Coastal Law and Policy (second edition American Bar Association 2015); See also Leila Sievanen and others, 'Linking Top-Down and Bottom-Up Processes Through the New US National Ocean Policy' (2011) 4 Conservation Letters 298.

82 National Ocean Council, National Ocean Policy Implementation Plan (National Ocean Council 2013) <obamawhitehouse.archives.gov/administration/eop/oceans/policy> accessed 1 October 2018.

83 National Ocean Council Marine Planning Handbook (National Ocean Council 2013) <obamawhitehouse.archives.gov/sites/default/files/microsites/ostp/final_marine _ planning_handbook.pdf> accessed 1 October 2018. 
CMSP recommendations and the Executive Order for the National Ocean Policy. Instead, the Plan and Handbook tend to stress the role of the federal government in supporting regional initiatives as opposed to leading them. In the meantime, Regional Planning Bodies had been appointed and in some cases have gone to work. In the Northeast Region where there was a long history of EBM coordination and in the Mid-Atlantic Region close to Washington, DC there was early start. In contrast, the South Atlantic, Gulf of Mexico, West Coast, Pacific Islands and Alaska Regions were much slower leaving the blocks. At the time of writing, only the Northeast R PB and Mid-Atlantic RPB plans have been completed and approved by the nOc. ${ }^{84}$ With another change of President, it is apparent that the support that existed in the White House for CMsP has evaporated. The Council on Environmental Quality has been physically removed from the White House and the NOC appears moribund. Web links to CMSP at the White House have been placed on temporary hold. However, no explicit actions have been taken to revoke the National Ocean Policy Executive Order so regional planning bodies continue to meet and the NOP remains on the books. ${ }^{85}$

\subsection{Marine Protected Area Management}

Marine protected areas in the United States have been established over a long period of time under various jurisdictions and management approaches. ${ }^{86} \mathrm{By}$ far the best known in federal waters are the National Marine Sanctuaries (NMS) established under the Marine Protection, Research, National Marine Sanctuaries Act 1972. In their original formulation these areas are not to be confused with marine National Parks or marine National Wildlife Refuges which were established under different legislation. They originally were conceived of as special area management designations where the national interest in protecting resources and environments gave impetus to having a facilitator to lead state, local, tribal and federal entities into developing appropriate management plans. The Sanctuary managers rely on other management entities like the National Marine Fisheries Service to manage fisheries, marine mammals,

84 Another driver of CMSP has been the controversy over and decision-making process for siting renewable offshore wind energy. Federal agencies involved with these efforts have participated in the regional planning processes. However, the results of marine spatial planning in federal waters in guiding the offshore planning by these agencies and leasing of offshore areas for wind do not take the regional plans into account.

85 See for example, West Coast Regional Planning Body, 'Agenda December 5-6, 2017' <www .westcoastmarineplanning.org> accessed 1 October 2018.

86 National Research Council, Marine Protected Areas: Tools for Sustaining Ocean Ecosystems (National Academies Press 2001). 
and endangered species, and the Coast Guard to manage shipping and recreational boating, smuggling and drug interdiction, etc. Gradually, the National Marine Sanctuary managers and the general public have begun to expect these areas to be managed for preservation as opposed to multiple use. In fact, the tension between conservation (meaning sustainable resource use) and preservation (strict protection mandates) has been at the core of MPA and National Marine Sanctuary management in the United States. This controversy in part led Congress in 2000 to direct NOAA to demonstrate that it has the resources to manage existing sanctuary areas before it would be permitted to designate more sites. It was not until 2014 that NOAA could reinitiate the designation process by demonstrating that it had the resources and by agreeing only to consider those areas where there was significant local support for a NMS designation. ${ }^{87}$

Given that there is a broad perception that oceans are being overused and degraded and that existing single sector management approaches appear incapable of reversing these trends, there are increasing demands for areas set aside from development to protect ecosystem functioning. ${ }^{88}$ The argument goes that if we cannot sustainably manage the oceans then we should strongly protect large areas that are significant for marine resources from all uses. ${ }^{89}$ This constitutes a type of ecosystem-based management. The counter argument is that it is better to apply ecosystem-based management across the whole marine environment and to use marine reserves and no-take M PAs where they are the best tool to manage for particular preservation trending results. ${ }^{90}$ It is outside

87 Kim Diana Connolly, 'Marine Protected Areas' in Donald C Baur and others (eds), Ocean and Coastal Law and Policy (second edition American Bar Association 2015).

88 Peter Jones, Ruth Murray and Ole Vestergaard, 'Marine Protected Areas: Securing Benefits for Sustainable Development' in United Nations Environmental Program (ed), Frontiers 2017: Emerging Issues of Environmental Concern (United Nations Environment Program 2017). This chapter explores the global implementation of the Sustainable Development Goal of $30 \%$ of national waters protected in MPAs. The Frontiers 2017 report is a most ambitious and optimistic expression of MPAs and represents an approach to Eвм. To be certain that approach would provide significant amounts of protection but it leaves open the management of the other $70 \%$. MPAs do not exist in isolation as their boundaries are porous to fish migrations, ocean currents, and activities that only transit their linear boundaries; See also Helen Kopnina and others, 'The "Future of Conservation" Debate: Defending Ecocentrism and the Nature Needs Half Movement' (2018) 217 Biological Conservation 140.

89 Jason Patlis and others, 'The National Marine Sanctuary System: The Once and Future Promise of Comprehensive Ocean Governance' (2014) 44 Environmental Law Reporter 10932; See also Linwood H Pendleton and others, 'Debating the Effectiveness of Marine Protected Areas' (2017) 75(3) ICES Journal of Marine Science 1156. Ibid. 
the scope of this chapter to resolve these differences in perspectives. Rather, the goal is to explore the progress being made to implement EBM using MPAs and networks of MPAs.

In order to encourage the development of MPA networks in US waters, President Clinton issued Executive Order 13158 - Marine Protected Areas. The purpose of the EO was to ' (...) (a) strengthen the management, protection and conservation of existing marine protected areas and establish new or expanded MPAS; (b) develop a scientifically based, comprehensive national system of M PAs representing diverse U.S. marine ecosystems, and the Nation's natural and cultural resources; and (c) avoid causing harm to MPAs through federally conducted, approved or funded activities.' The EO defines Marine Protected Area as '(...) any area of the marine environment that has been reserved by Federal, State, territorial, tribal or local laws or regulations to provide lasting protection for part or all of the natural and cultural resources therein. ${ }^{91}$ Most importantly, the EO does not alter existing legislation for designating MPAS nor does it affect Indian treaty rights or US trust responsibilities and it does not 'create any right or benefit, substantive or procedural, enforceable in law or equity by a party against the United States, its agencies, its officers, or any person. ${ }^{92}$ In order to carry out this EO, the Department of Commerce is directed to establish a Marine Protected Area Federal Advisory Committee (Section 8(c)) and also to establish a Marine Protected Area Center (Section 8(e)) in cooperation with the Department of Interior.

Beyond this EO President Clinton also used EO 13178 to initiate planning for the Northwestern Hawaiian Islands Coral Reef Ecosystem Reserve as an eventual National Marine Sanctuary (added to by EO 13196 to finalize the Reserve and formalize the process for designating a NMS). ${ }^{93}$ In this way he was able to circumvent the Congressional opposition to the establishment of new National Marine Sanctuaries. This was a bold move requiring careful coordination with the existing National Wildlife Refuges and the State of Hawaii for state waters to be included in the reserve. The proposed reserve would extend approximately $1,200 \mathrm{~nm}$ and be $100 \mathrm{~nm}$ in width encompassing 3.5 million acres. In addition, President Clinton designated the California Coastal National Monument using Presidential Proclamation No 7264 January 11, 2000

91 Executive Order 13158, Marine Protected Areas, May 26, 200o. Purpose Section 1 (a)-(c); MPA definition Section 2 <http://www.presidency.ucsb.edu/ws/?pid=61650 $>$ accessed December 12, 2017.

92 Ibid. Section 8.

93 Executive Order 13178 December 4, 2000 Northwestern Hawaiian Islands Coral Reef Ecosystem Reserve EO 13196 Final Northwestern Hawaiian Islands Coral Reef Ecosystem Reserve, January 21, 2001. 
(President Obama expanded this National Monument by Proclamation No 9089 March 11, 2014)..$^{94}$

The American Antiquities Act 1906 (AAA 1906) as outlined above is another tool by which very large MPAs have been designated in recent years. Under this Act the President is authorized by Congress to designate objects of historic or scientific interest as National Monuments but recent ocean-based designations have been fraught with controversy. However, Presidential authority to make these designations has survived legal and political challenge. ${ }^{95}$ For the most part the Antiquities Act has been used to designate terrestrial sites that hold cultural artifacts or other significance whereas cultural artifacts are much less abundant in the ocean (with the exception of some islands) and the designation has served preservation goals. President Bush, in 2006-2007 used Proclamations to designate the Papahānaumokuākea Marine National Monument (Northwest Hawaiian Islands Marine National Monument) ${ }^{96}$ and then in 2009 at the end of his term in office, to designate the Marianas Trench, Pacific Remote Islands and Rose Atoll Marine National Monuments. Not to be outdone, President Obama expanded the size of the Pacific Remote Islands MNM in 2014. ${ }^{97}$ In 2016 President Obama Proclaimed the Northeast Canyons and Seamounts Marine National Monument as the first MNM in the Atlantic. ${ }^{98}$

94 Kim Diana Connolly, 'Marine Protected Areas' in Donald C Baur and others (eds), Ocean and Coastal Law and Policy (second edition American Bar Association 2015).

95 Carol Hardy Vincent and Kristina Alexander, 'National Monuments and the Antiquities Act' (Congressional Research Service 2010) 7-5700 < digital.library.unt.edu/ark:/67531/ metadc463245/> accessed 1 October 2018.

96 John N Kittinger and others, 'Marine Protected Areas, Multiple-Agency Management and Monumental Surprise in the Northwest Hawaiian Islands' [2011] Journal of Marine Biology 1 Article ID 241374.

97 White House Presidential Proclamation Barack Obama, 'Pacific Remote Islands Marine National Monument Expansion' <obamawhitehouse.archives.gov/the-press -office/2014/og/25/presidential-proclamation-pacific-remote-islands-marine-national -monumen> accessed 1 October 2018; See also Enric Sala and others, Expansion of the U.S. Pacific Remote Islands Marine National Monument: Report to the United States Government (May 20, 2014) http://www.conservehi.org/newsitems/PRIMNM_Science_Report.pdf> accessed December 10, 2017.

98 US Department of Interior, 'Secretaries Pritzker, Jewell Applaud President's Designation of Northeast Canyons and Seamounts Marine National Monument', September 15, $2016<$ www.doi.gov/pressreleases/secretaries-pritzker-jewell-applaud-presidents -designation-northeast-canyons-and> (sic) accessed December 13, 2017; President of the United States Barack Obama, Proclamation 9496-Northeast Canyons and Seamounts Marine National Monument, September 15, 2016 < obamawhitehouse.archives.gov/the -press-office/2016/og/15/presidential-proclamation-northeast-canyons-and-seamounts -marine> accessed 1 October 2018. 
The result is that large areas of remote oceanscape were given protected status ${ }^{99}$ but the management planning for them was in limbo. ${ }^{100}$ This is because under the AAA 1906, even when the President may have designated the agency to administer the area, in this case the Department of Commerce, there is a lack of legislative direction as to how an area should be managed. ${ }^{101}$ The designation of large marine national monuments has contributed fuel to an already heated debate over Presidential vs. Congressional authority. ${ }^{102}$

Returning to the question of progress in implementing a MPA network in the United States, the prime attention is given to the National Marine Sanctuaries. Considerable work is being performed using an Евм approach to development of sanctuary management plans and more recently sanctuary condition reports. However, the extent to which they contribute to a MPA network varies by location, with the California NMS offering greater connectivity than other areas. ${ }^{103}$ According to the most recent data (January 2017) from the US MPA Center, the US has more than 1,200 MPAs covering more than 3.2 million square kilometers which is $26 \%$ of water areas in the US Exclusive Economic Zone (EEZ). ${ }^{104}$ Some $23 \%$ of the US EEZ is closed to commercial fishing but only $3 \%$ of US waters is in no-take MPAs where all fishing is prohibited. Not surprisingly, $96 \%$ of the area designated as MPAs is in the Pacific Islands where very large Marine National Monuments have been proclaimed under the AAA 1906. Only $1 \%$ of MPA areas are under coastal state management with approximately 1,000 sites designated. ${ }^{105}$

99 Kim Diana Connolly, 'Marine Protected Areas' in Donald C Baur and others (eds), Ocean and Coastal Law and Policy (second edition American Bar Association 2015).

100 Christopher Pala, 'Giant Marine Reserves Pose Vast Challenges' (2013) 339 Science 640.

101 Katherine R Peet, 'Documenting and Evaluating a New Approach to Establishing LargeScale Marine Protected Areas in the U.S.' Masters of Marine Affairs, School of Marine and Environmental Affairs, University of Washington, Seattle, Washington, USA (2014).

102 Mark Stephen Squillace and others, 'Presidents Lack the Authority to Abolish or Diminish National Monuments' (2017) 103 Virginia Law Review Online 55; See also John Yoo and Todd Gaziano, 'Presidential Authority to Revoke or Reduce National Monument Designations' (American Enterprise Institute 2017).

103 James Lindholm and Robert Pavia (eds), 'Examples of Ecosystem-Based Management in National Marine Sanctuaries: Moving From Theory to Practice' (oMs-10-22 39 US Department of Commerce, National Oceanic and Atmospheric Administration, National Ocean Service, Office of National Marine Sanctuaries 2010).

104 Despite the fact that the United States has not agreed to the IUCN World Parks Congress goal of $30 \%$ of national waters in MPAs (or the Aichi $10 \%$ goal), the recent additions of very large areas in the Pacific and Atlantic appear to show the US is close to meeting the IUCN goal and appears to exceed the Aichi target.

105 National Marine Protected Areas Center, 'Conserving Our Oceans One Place at a Time' (2017) < https://nmsmarineprotectedareas.blob.core.windows.net/marineprotectedareas 
Executive Order 13158 calls for federal agencies to develop a scientifically based and comprehensive national system of MPAs that preserve representative habitats in different geographic regions. Out of an analysis of 1,628 MPAs [some of which do not meet minimum criteria for inclusion in the MPA Inventory] in 19 defined ecoregions, the M PA Center states that the M PAs are 'nominally' representative of major marine ecosystems with $70 \%$ of habitat types, $82 \%$ of bird species, invertebrates and algal ecosystem features, $71 \%$ of select fish, marine mammals and sea turtle species and EsA listed species, and $87 \%$ of select ecosystem processes. Authors of the assessment report caution that these numbers represent a first rough cut to estimate comprehensiveness and representative preservation of habitats and species and the presence or absence of data sorting does not adequately account for viability/sustainability of the measure. ${ }^{106}$ Note, as well, that connectivity is not assessed for the sites in the MPA Inventory.

These official results stack up favorably with the perspective that MPA networks, as inventoried by the US, can be a useful tool in promoting EBM, even if they are not fully capable of being considered as a sufficient approach to в Вм. However, this somewhat contrasts with the findings of one recent study of North American MPAs that compares US performance with that of Canada and Mexico. Four criteria for assessment of protection were applied, i.e., legal designation, permanence, presence of an administrative structure, and a completed management plan. ${ }^{107}$ MPAs that met all the criteria were included in the data base. In this assessment of continental US MPAs they found 91 MPAS that were considered fully protected totaling $0.03 \%$ of the US EEZ. This does not include the huge areas in the Pacific Islands region recently proclaimed. If these areas are included they account for a large part of the difference between what is reported officially and the findings of others. ${ }^{108}$

As with other US approaches to EBM, it is difficult to agree on ways to systematically assess benefits and costs of implementing Е вм through a national inventory program for MPAs.

-prod/media/archive/pdf/fac/mpas_of_united_states_conserving_oceans_1113.pdf> accessed December 13, 2017.

106 National Marine Protected Areas Center, 'Representativeness of Marine Protected Areas of the United States' (2015) <http://marineprotectedareas.noaa.gov/dataanalysis/ mpainventory/> accessed December 13, 2017.

107 Sabine Jessen and others, 'Measuring MPAs in Continental North America: How Well Protected Are the Ocean Estates of Canada, Mexico and the USA' (2017) 4 Frontiers in Marine Science 279 .

108 Kaitlin LP Shugart-Schmidt and others, 'SeaStates G20 2014: How Much of the Seas Are G20 Nations Really Protecting?' (2015) 115 Ocean and Coastal Management 25. 
Weaving together the multiple strands that represent ecosystem-based management of the oceans in the US does not produce a tapestry. Rather it seems to produce an abstract weaving or collage with multiple clumps and lots of holes. Starting with the patchwork fabric of the approximately 140 laws that apply to marine management and governance, no clear mandates for EBM emerge that can be enforced by agencies or by others seeking to take agencies who ignore them to court in our litigious system. The complex of laws does inject important elements of ЕВM through requirements to manage fisheries sustainably, to avoid extinctions, to protect marine mammals, to set aside marine protected areas, and to identify the environmental impacts of major federal actions. The cumulative effect of these laws does promote direct and indirect consideration of precautionary management of the marine environment and together they form a fragmented foundation on which other ecosystem-based management approaches can build. Nevertheless, the appetite in Congress for comprehensive, Е Вм oriented legislation appears to be very small and no strong groundswell of popular support for legislative action is expected under the prevailing political climate.

Absent direction from Congress, federal agencies and the Executive Branch of government have been taking the initiative to build Е Вм from existing legislation. NOAA and its regional fishery management councils have been exploring how management actions under Fishery Ecosystem Plans can improve management outcomes based on utilizing the best available scientific information. The science considered is much broader than single species stock assessments and includes food web interactions, habitat feedback effects, bycatch reduction, etc. The sum of multiple actions conducive to good fishery management including ecosystem dynamics has brought ecosystem level benefits to fisheries management and reduced the ecosystem footprint. However, fisheries management lacks control over marine pollution, extractive activities, and so on. Moreover, its own determinations with respect to acceptable ecosystem tradeoffs may not match preferences held by others, e.g., biodiversity preservation or ecosystem restoration. Ecosystem-based fisheries management does not encompass all of societal values or preferences, but it does produce more resilient and sustainable fisheries.

At a national level, the discourse about application of ЕВM has led to policy recommendations for ЕВМ and the quest is on for more holistic approaches to management. Three of the most promising Ев $\mathrm{M}$ initiatives have been reviewed: Integrated Ecosystem Assessments, Coastal and Marine Spatial Planning, and Marine Protected Area Networks. IEAs are a product of NOAA as the premier 
ocean science and management agency searching for a role it could play to implement Евм. The idea to consolidate what is known about the ecosystem and its dynamics into usable products and advice on the regional level in an IEA may be seen as a slightly odd approach. In any event, IEAs were neither welcomed nor resisted yet have not been widely implemented. Unfortunately the lack of budgetary resources severely limited the process of IEA development in a comprehensive regional manner. Surprisingly, it might be considered to have been sabotaged by a national shift of attention to CMSP under the National Ocean Policy. CMSP was led by the Executive Branch and a receptive President who was responding to strong support from environmental and good government advocates. President Obama seized the opportunity to implement ЕВМ through regional marine planning as a cornerstone of a declaration of a national ocean policy. However, the enthusiasm for a national ocean policy and especially for CMSP was not shared by marine industries and coastal resource dependent communities. In part, this reluctance to join the CMSP movement arose from the concern that it was driven by environmental advocates wanting more restrictive management for ocean uses and for closing off areas in MPAS. In places where industries and coastal resource dependent communities have joined in CMSP there are compelling conflicts that drive the desire for cooperation and CMSP represents a good governance solution. In the meantime, Marine Protected Area designations also received a tremendous boost from the Executive Branch with designations of very large Marine National Monuments by several Presidents. Further, the interest in developing MPAs in coastal waters to meet specific management purposes or preservation goals was captured in the MPA inventory efforts.

At present, these initiatives have more or less stalled for a number of reasons, not the least of which is that stakeholders involved in these various initiatives have focused their energies on one but not all. Few environmental nongovernmental organizations or marine industry groups have the interest or resources to engage in more than one process. As an analyst I think it is possible to suggest that there is a big picture solution to weaving these strands together. First, fishery managers must continue to develop and implement ЕвFм but they must also engage constructively in other broader Евм initiatives. ${ }^{109}$ Next, NOAA and its partners must develop IEAs regionally on scales that match management needs - these can be nested IEAs with specific attention to

109 Elliott A Norse, 'Ecosystem-Based Spatial Planning and Management of Marine Fisheries: Why and How?' (2010) 86:2 Bulletin of Marine Science 179; See also Holger Janßen and others, 'Integration of Fisheries into Marine Spatial Planning: Quo Vadis?' (2016) 120 Estuarine, Coastal and Shelf Science 1. 
small-scale demands and the opportunities to scale up to broader ecosystem levels. ${ }^{110}$ Third, IEAs are a core component of CMSP because they assemble best available scientific information and organize it to address ecosystem status, trends and forecasts. The consolidation of ecosystem information in IEA helps identify conflicts and opportunities on a regional scale to provide the scientific basis for marine spatial planning. After all, the usual first step in CMSP is to pull together all the same information that would be contained in an IEA. Fourth, MPA designation is a tool that can be used in CMSP to embed MPAS as appropriate into a broader matrix of ЕвM management measures for the whole ecosystem. ${ }^{111}$

Conceptually, these seemingly simple ways of bringing the best attributes of the different approaches to ЕВ $\mathrm{M}$ into a consolidated approach seems possible and even logical, but it proves to be an elusive goal. The large question that must be addressed is how to provide the administrative structure and to prioritize the human and fiscal resources to make ввм feasible. Absent Congressional interest and leadership to pursue comprehensive legislation that would prioritize, reorganize and designate leadership responsibilities and budgetary support across agencies and programs, this will not happen. With strong leadership at the top of the Executive Branch and cooperation among federal agencies it can happen but there does not appear any likelihood that ocean issues will attract such attention. The courts can enforce existing legislation, but they cannot dictate policy.

Based on these observations the most optimistic future that can be imagined and hoped for would be that each of these threads will continue to develop and that a gradual recognition of the interdependence of these approaches can evolve. This kind of evolution can be observed with respect to IEAs being used in fisheries management and marine spatial planning on the West Coast of the US. Perhaps the threat of climate change as a common enemy can coalesce these efforts if it does not, in fact, defeat them all. ${ }^{112}$

\footnotetext{
110 Phillip S Levin and others, 'Integrated Ecosystem Assessments: Developing the Scientific Basis for Ecosystem-Based Management of the Ocean' (2009) 7 Public Library of Science Biology 23.

111 Tundi Agardy, Giuseppe Notarbartolo de Sciara and Patrick Christie, 'Mind the Gap, Addressing the Shortcomings of Marine Protected Areas Through Large Scale Marine Spatial Planning' (2011) 35 Marine Policy 226.

112 M Ruckelshaus and others, 'Securing Ocean Benefits for Society in the Face of Climate Change' (2013) 40 Marine Policy 154.
} 
On June 18, 2018 President Trump issued Executive Order 13840 Ocean Policy To Advance the Economic, Security and Environmental Interests of the United States substituting his vision for ocean management for that of President Obama. The Executive Order reflects the decided shift of ocean policy seen so far under the Trump administration with an emphasis on ocean utilization, opening nearly the whole continental shelf to oil and gas leasing, potential roll-backs of protections in Marine National Monuments, withdrawal of the United States from the Paris Climate Agreement, etc.

Importantly, the Executive Order does not change existing federal laws. Deadlock in Congress means that Congress is unlikely to significantly amend ocean management in federal law. Numerous suits have been brought by environmental and other interests to challenge administrative changes and asking the Courts to ensure that laws and processes are being followed. Congressional control over appropriations has shown signs that Obama era policies can be blocked or defunded by riders inserted in budget legislation (e.g., Section 505 of the Energy and Water, Legislative Branch and Military Construction and Veterans Affairs Appropriations Act, 2019 states 'None of the funds made available by this Act may be used to further implementation of the coastal and marine spatial planning and ecosystem-based management components of the National Ocean Policy developed under Executive Order No. 13547 [...].'

At present it is difficult to foresee the extent to which the change in administrations will result in actual changes in ocean use. The stagnation in Congressional leadership on the oceans means that little change can be expected from that Branch. The Courts may be called upon to uphold existing laws. Administrative agencies are used to adapting to changes at the top by continuing to do the tasks that they are assigned by legislation. Science-informed ecosystembased fisheries management has considerable support in most fishing regions where climate change is increasing the demand for prediction of harvest levels and locations. Regional and state level experience with marine spatial planning is on a steep learning curve. The limits and strengths of planning will guide future planning efforts at appropriate scales and for appropriate purposes. Marine protected areas as a tool in an ecosystem approach are likely to be maintained although the pace of designation may slow and protections may be rolled back for some of the large marine national monuments. Thus, the primary conclusion still holds: the United States will continue to weave together the web of ocean policies aided by an understanding of how an ecosystem approach can improve ocean planning and governance albeit with less leadership and support. 


\section{Bibliography}

\section{Books}

Anderson, FR, NEPA in the Courts: A Legal Analysis of the National Environmental Policy Act (Johns Hopkins University Press for Resources for the Future 1973).

Bass RE, Herson AI and Bogdan KM, The NEPA Book: A Step-by-Step Guide on How to Comply with the National Environmental Policy Act (2nd edition Selano Press Books 2001).

Belgano A and Fowler CW, Ecosystem-Based Marine Fishes: An Evolving Perspective (Cambridge University Press 2011).

Boyce M and Haney A, Ecosystem Management: Applications for Sustainable Forest and Resources (Yale University Press 1996).

Bramwell A, Ecology in the 2oth Century: A History (Yale University Press 1989).

Brinkley D, Rightful Heritage: Franklin D. Roosevelt and the Land of America (HarperCollins 2016).

Burroughs J, The Complete Nature Writings of John Burroughs (WH Wise 1931).

Huth H, Nature and the American: Three Centuries of Changing Attitudes (University of Nebraska Press 1957).

Leopold A, The Sand County Almanac, and Sketches from Here and There (Oxford University Press 1949).

Link JS, Ecosystem-Based Fisheries Management: Confronting Tradeoffs (Cambridge University Press 2010).

Liroff RA, A National Policy for the Environment (Indiana University Press 1976).

Lunde D, The Naturalist Theodore Roosevelt, A Lifetime of Exploration, and the Triumph of American Natural History (Crown Publishers 2016).

Marsh JP, Man and Nature: Or, Physical Geography as Modified by Human Action (Third edition, Lowenthal D (ed), The Belknap Press of Harvard University Press 1974).

McIntosh RP, The Background of Ecology: Concept and Theory (Cambridge University Press 1985 Reprint 1988).

Nash R, Wilderness and the American Mind (Yale University Press 1967).

Thoreau HD, Walden (J. Lyndon Shanley (ed) Princeton University Press 2007).

Walls LD, Henry David Thoreau: A Life (The University of Chicago Press 2017).

Walters DJ and Martell SJD, Fisheries Ecology and Management (Princeton University Press 2004).

Wulf A, The Invention of Nature: Alexandervon Humboldt's New World (Alfred A Knopf 2015).

Yoo J and Gaziano T, Presidential Authority to Revoke or Reduce National Monument Designations (American Enterprise Institute 2017). 


\section{Official Publications}

Buck EH, 'Congressional Research Service Report for Congress: Marine Ecosystem Management' (Congressional Research Service 1993).

Committee on Natural Resources, US House of Representatives, Subcommittee on Water, Power and Oceans, 'Oversight Hearing: Implications of President Obama's National Ocean Policy'(SerialNo.114-43May 17, 2016, US GovernmentPrintingOffice) <https://www.gpo.gov/fdsys/pkg/CHRG-114hhrg20220/pdf/CHRG-114hhrg20220 .pdf $>$ accessed December 17, 2017.

Ecosystem Sciences and Management Working Group, NOAA Science Advisory Board 'Exploration of Ecosystem-Based Fishery Management in the United States' (NOAA Science Advisory Board 2014) <ftp://ftp.oar.noaa.gov/SAB/sab//Reports/SAB\%2o EBFM\%2oReport\%2oto\%20NOAA_July\%202014_Final.pdf> accessed 1 October 2018.

Ecosystem Sciences and Management Working Group, NOAA Science Advisory Board, 'NOAA Response to Exploration of Ecosystem-Based Fishery Management in the United States' (NOAA Science Advisory Board 2015) <ftp://ftp.oar.noaa.gov/SAB/ sab/Meetings/2015/August/NOAA_Resp_EBFM_2015_Final\%20(2).pdf> accessed 1 October 2018.

Executive Office of the President, Executive Order 13158, Marine Protected Areas, May 26, 2000. Purpose Section 1 (a)-(c); MPA definition Section $2<$ www.presidency.uscb $. e d u / w s /$ ?pid=61650 $>$ accessed December 12, 2017.

Executive Office of the President, Executive Order 13178 December 4, 2000 Northwestern Hawaiian Islands Coral Reef Ecosystem Reserve EO 13196 Final Northwestern Hawaiian Islands Coral Reef Ecosystem Reserve, January 21, 2001.

External Ecosystem Task Team (EETT), NOAA Science Advisory Board, 'Evolving an Ecosystem Approach to Science and Management Throughout NOAA and its Partners: Final Report' (NOAA Science Advisory Board 2006) <httpp//sab.noaa.gov/ sites/SAB/Reports/EETT/eERRT\%20-\%2oFinal\%2oReport\%2oto\%2oNOAA\%2o Oct\%2006.pdf > accessed 1 October 2018.

Fluharty D and Cyr N, 'Implementing Ecosystem-Based Management of Fisheries in the Context of US Regional Fisheries Management: Recommendations of the NMFS Ecosystem Principles Advisory Panel' (2001) 42 CalCOFI Reports 66.

Harvey C and others, 'NOAA's Integrated Ecosystem Assessment Program: California Current Region 3-Year Work Plan (FY2016-FY2018)' (NOAA California Region 2017) <www.integratedecosystemassessment.noaa.gov/Assets/iea/gulf/documents/ regional-work-plans/NOAA-IEA-Work-Plan-CCIEA.pdf> accessed 1 October 2018.

Hobart WL, Baird's Legacy: The History and Accomplishments of NOAA's National Marine Fisheries Service, 1871-1996 (Technical Memorandum NMFS F/sPO-18 United 
States Department of Commerce, National Oceanic and Atmospheric Administration, National Marine Fisheries Service 1995).

Jones P, Murray R and Vestergaard O, 'Marine Protected Areas: Securing Benefits for Sustainable Development' in United Nations Environmental Program (ed), Frontiers 2017: Emerging Issues of Environmental Concern (United Nations Environment Program 2017).

Lenfest Ocean Program, Building Effective Fishery Ecosystem Plans: Report from the Lenfest Fishery Ecosystem Task Force (Lenfest Ocean Program 2016) 6o <https:// www.lenfestocean.org/news-and-publications/published-paper/building -effective-fishery-ecosystem-plans $>$ accessed 1 October 2018.

Levin PS and others, Integrated Ecosystem Assessments (NOAA Technical Memorandum NMFS-NWFSC-92 U.S. Department of Commerce 2008).

Lindholm J and Pavia R (eds), Examples of Ecosystem-Based Management in National Marine Sanctuaries: Moving From Theory to Practice (OMS-10-22 39 US Department of Commerce, National Oceanic and Atmospheric Administration, National Ocean Service, Office of National Marine Sanctuaries 2010).

Morrissey W, Zinn J and Corn L, 'Ecosystem Management in the Federal Agencies' (Congressional Research Service 1994).

Murawski SA and Matlock GC (eds), Ecosystem Science Capabilities Required to Support NOAA's Mission in the Year 2020 (NOAA Technical Memorandum NMFS-F/sPO-74 US Department of Commerce 2006).

National Marine Fishery Service, Ecosystem Principles Advisory Panel, 'EcosystemBased Fisheries Management: A Report to Congress by the Ecosystem Principles Advisory Panel' (National Marine Fisheries Service, National Oceanic and Atmospheric Administration 1999).

National Marine Fisheries Service, Requirements for an Ecosystem Approach to Management of Living Marine Resources (Department of Commerce/NOAA/NM FS 2004). National Marine Fisheries Service, The State of Science to Support an Ecosystem Approach to Regional Fishery Management: Pursuant to the Magnuson-Stevens Fishery Conservation and Management Act, Section 4o6 $(f)$ Report to Congress. (NOAA Technical Memo NMFS F/sPo-96 National Marine Fisheries Services 2009).

National Marine Fisheries Service, 'Ecosystem-Based Fisheries Management Policy' NMFS Policy Directive 01-120 May 23, 2016 <www.fisheries.noaa.gov/resource/ document/ecosystem-based-fisheries-management-policy $>$ accessed 1 October 2018.

National Marine Fisheries Service, 'NOAA Fisheries Ecosystem-Based Fisheries Management Road Map' NMFs Instruction 01-120-01 November 2016. <https://www .st.nmfs.noaa.gov/Assets/ecosystems/ebfm/EBFM_Road_Map_final.pdf> accessed 1 October 2018.

National Marine Protected Areas Center, 'Conserving Our Oceans One Place at a Time' (2017) < https://nmsmarineprotectedareas.bob.core.windows.net/marineprotected 
areas-prod/media/archive/pdf/publications/conserving-our-oceans-one-place-at -a-time-v11.pdf $>$ accessed December 13, 2017.

National Marine Protected Areas Center, 'Representativeness of Marine Protected Areas of the United State' (2015) <https://nmsmarineprotectedareas.blob.core .windows.net/marineprotectedareas-prod/media/archive/pdf/fac/mpas_of_ united_states_conserving_oceans_1113.pdf> accessed December 13, 2017.

National Ocean Council, National Ocean Policy Implementation Plan (NOC 2013) <obamawhitehouse.archives.gov/administration/eop/oceans/policy> accessed 1 October 2018.

National Ocean Council, Marine Planning Handbook (NOC 2013) < obamawhitehouse .archives.gov/sites/default/files/microsites/ostp/final_marine_planning_handbook .pdf $>$ accessed 1 October 2018.

National Oceanic and Atmospheric Administration, Chesapeake Bay Fisheries Ecosystem Plan (NOAA Chesapeake Bay Office 2004).

NOAA Fisheries Office of Science \& Technology 'NOAA's Integrated Ecosystem Assessment Program (IEA): Ecosystem Science Review' (2016) <www.st.nmfs.noaa .gov/Assets/science_program/ecosystem-program-review/IEA/EcosystemScience ReviewOST_IEA_Final.pdf $>$ accessed 1 October 2018.

National Research Council, Marine Protected Areas: Tools for Sustaining Ocean Ecosystems (National Academies Press 2001).

National Technical Information Service, The Ecosystem Approach: Healthy Ecosystems and Sustainable Economies, Volume 1 (NTIS 1995).

Office of Environment and Planning, Executive Office of the President' 'Memorandum of Understanding to Foster the Ecosystem Approach' (1995) <https://www.fhwa.dot .gov/legsregs/directives/policy/memoofun.htm> accessed December 10, 2017.

President of the United States Barack Obama, 'Proclamation 9496-Northeast Canyons and Seamounts Marine National Monument' September 15, 2016 <obamawhite house.archives.gov/the-press-office/2016/og/15/presidential-proclamation -northeast-canyons-and-seamounts-marine> accessed 1 October 2018.

Pew Oceans Commission, America's Living Oceans: Charting a Course for Sea Change (Pew Foundation 2003) available at <https://www.pewtrusts.org/ /media/assets/ 2003/06/02/poc_summary.pdf > accessed 1 October 2018.

Puget Sound Partnership, The 2016 Action Agenda for Puget Sound: Comprehensive Plan <www.psp.wa.gov/action-agenda-document.php> accessed 1 October 2018.

Puget Sound Partnership, 'The 2016 Action Agenda for Puget Sound: Implementation Plan' <www.psp.wa.gov/action-agenda-document.php> accessed 1 October 2018.

Sala E and others, Expansion of the U.S. Pacific Remote Islands Marine National Monument: Report to the United States Government (May 20, 2014) <http://www .conservehi.org/newsitems/PRIMNM_Science_Report.pdf> accessed December 10, 2017. 
US Department of Interior, 'Secretaries Pritzker, Jewell Applaud President's Designation of Northeast Canyons and Seamounts Marine National Monument' September 15, 2016 < obamawhitehouse.archives.gov/the-press-office/2014/og/25/ presidential-proclamation-pacific-remote-islands-marine-national-monumen> accessed 1 October 2018.

US Commission on Ocean Policy, An Ocean Blueprint for the 21st Century: Final Report (US Commission on Ocean Policy 2004) available at <https://govinfo.library .unt.edu/oceancommission/documents/full_color_rpt/ooo_ocean_full_report.pdf> accessed December 11, 2017.

Vincent $\mathrm{CH}$ and Alexander K, 'National Monuments and the Antiquities Act' (7-5700 R41330 Congressional Research Service 2010) < www.crs.gov> accessed December 13, 2017.

West Coast Governor's Agreement on Ocean Health, Integrated Ecosystem Assessment (IEA) Action Coordination Team, Final Work Plan (West Coast Governors 2012) <www.westcoastoceans.org/media/ieaworkplanfinalo4242012.pdf> accessed December 13, 2017.

White House Council on Environmental Quality, Final Recommendations of the Interagency Ocean Policy Task Force (Council on Environmental Quality 2010) <www.nsf .gov/geo/opp/opp_advisory/briefings/nov2010/optf_finalrecs.pdf $>$ accessed 1 October 2018.

The White House, Office of the Press Secretary, Executive Order 13547 Stewardship of the Ocean, Our Coasts, and the Great Lakes, July 19, 2010. Section 3 (b) <https:// obamawhitehouse.archives.gov/the-press-office/executive-order-stewardship -ocean-our-coasts-and-great-lakes > accessed December 16, 2017.

White House, Office of the Press Secretary, 'Memorandum for the Heads of Executive Departments and Agencies, National Policy of the Oceans, Our Coasts, and the Great Lakes' June 12, 2009 < https://obamawhitehouse.archives.gov/administration/ eop/oceans/policy> accessed December 16, 2017.

White House, Presidential Proclamation Barack Obama 'Pacific Remote Islands Marine National Monument Expansion' <https://obamawhitehouse.archives.gov/ the-press-office/2014/og/25/presidential-proclamation-pacific-remote-islands -marine-national-monument> accessed December 10, 2017.

Wilkinson EB and Abrams K, 'Benchmarking the 1999 EPAP Recommendations with Existing Fishery Ecosystem Plans' (NMFs Technical Memorandum NMFS-OSF-5 US Department ofComerce/NOAA/NMFS 2015).

\section{Book Chapters}

Barnes C, Bozzi L and McFadden K, in Crum K and Mechling EJ (eds), Exploring an Ecosystem Approach to Management: A Review of the Pertinent Literature (National Oceanic and Atmospheric Administration 2012). 
Baur DC, Gosliner ML and Young NM, 'The Law of Marine Mammal Conservation' in Baur DC, Eichenberg T and Sutton M (eds), Ocean and Coastal Law and Policy (American Bar Association 2007).

Connolly KD, Schorr JL and Misenko D, 'Marine Protected Areas' in Baur DC, Eichenberg T and Sutton M (eds), Ocean and Coastal Law and Policy (American Bar Association 2007).

Connolly KD, 'Marine Protected Areas' in Baur DC and others (eds), Ocean and Coastal Law and Policy (second edition American Bar Association 2015).

Erickson AL, Caldwell MR and Koehm JZ, 'Smart Ocean Planning: Drivers, Enabling Conditions, and Global Examples' in Baur DC and others (eds), Ocean and Coastal Law and Policy (American Bar Association 2015 second edition).

Irvin WR and Bean M, 'The Endangered Species Act and Marine Species' in Baur DC, Eichenberg T and Sutton M (eds), Ocean and Coastal Law and Policy (American Bar Association 2007).

Parenteau PA, Baur DC and Schorr JL, 'Legal Authorities for Ecosystem-Based Management in US Coastal and Ocean Areas' in Baur DC, Eichenberg T and Sutton M (eds), Ocean and Coastal Law and Policy (American Bar Association 2007).

\section{Journal Articles}

Agardy T, Notarbartolo de Sciara G and Christie P, 'Mind the Gap, Addressing the Shortcomings of Marine Protected Areas Through Large Scale Marine Spatial Planning' (2011) 35 Marine Policy 226.

Arkema, K, Abramson S and Dewsbury B, 'Marine Ecosystem Management: From Characterization to Implementation' (2006) 4 Frontiers in Ecology and Management 525 .

Biedenweg K, Harguth H and Stiles K, 'The Science and Politics of Human Well-being: A Case Study in Cocreating Indicators for Puget Sound Restoration' (2017) 22 Ecology and Society 3 .

Bundy A and others, 'Strong Fisheries Management and Governance Positively Impact Ecosystem Status' (2017) 18 Fish and Fisheries 412.

Christensen NL and others, 'The Report of the Ecological Society of American Committee on the Scientific Basis for Ecosystem Management' (1996) 6 Ecological Applications 665 .

Collie JS and others, 'Marine Spatial Planning in Practice' (2013) 117 Estuarine, Coastal and Shelf Science 1.

Crowder LB and others, 'Resolving Mismatches in US Ocean Governance' (2006) 313 Science 617 .

Dell'Apa A and others, 'The Status of Marine and Coastal Ecosystem-Based Management Among the Networks of U.S. Federal Programs' (2015) 6o Marine Policy 249. 
deReynier YL, Levin PS and Shoji NL, 'Bringing Stakeholders, Scientists and Managers Together Through an Integrated Ecosystem Assessment Process' (2010) 34 Marine Policy 534 .

Engler C, 'Review: Beyond Rhetoric: Navigating the Conceptual Tangle Towards Effective Implementation of the Ecosystem Approach to Oceans Management' (2015) 23 Environmental Review 288.

Fluharty D, 'Recent Developments at the Federal Level in Ocean Policymaking in the United States' (2013) 40 Coastal Management 209.

Foran $\mathrm{M}$ and others, 'Relating Mandates in the United States for Managing the Ocean to Ecosystem Goods and Services Demonstrates Broad but Varied Coverage' (2016) 3 Frontiers in Marine Science 5 .

Griffis RB and Kimball KW, 'Ecosystem Approaches to Coastal and Ocean Stewardship' (1996) 6 Ecological Applications 708.

Janßen H and others, 'Integration of Fisheries into Marine Spatial Planning: Quo Vadis?' (2016) 120 Estuarine, Coastal and Shelf Science 1.

Jessen S and others, 'Measuring MPAs in Continental North America: How Well Protected Are the Ocean Estates of Canada, Mexico and the USA' (2017) 4 Frontiers in Marine Science 279.

Kale, S, 'Ecology Comes of Age: NEPAs Lost Mandate' (2010) 21 Duke Environmental Law and Policy Forum 113.

Kelly RP and others, 'Harnessing DNA to Improve Environmental Management: Genetic Monitoring Can Help Public Agencies Implement Environmental Laws' (2014) 344 Science 1455 .

Kittinger JN and others, 'Marine Protected Areas, Multiple-Agency Management and Monumental Surprise in the Northwest Hawaiian Islands' [2011] Journal of Marine Biology Article ID 241374.

Kopnina H and others, 'The 'Future of Conservation' Debate: Defending Ecocentrism and the Nature Needs Half Movement' (2018) 217 Biological Conservation 140.

Levin PS and others, 'Integrated Ecosystem Assessments: Developing the Scientific Basis for Ecosystem-Based Management of the Ocean' (2009) 7 PLoS Biology 1.

Levin PS and others, 'Guidance for Implementation of Integrated Ecosystem Assessments: A US Perspective' (2013) 71 ICES Journal of Marine Science 1198.

Link JS, 'Ecological Considerations in Fisheries Management: When Does It Matter?' (2002) 27:4 Fisheries 10.

Link JS, 'What Does Ecosystem-Based Fisheries Management Mean?' (2002) 27:4 Fisheries 18.

Lowell N and Kelly RP, 'Evaluating Agency Use of 'Best Available Science' Under the United States Endangered Species Act' (2016) 196 Biological Conservation 53.

Lubchenco J and others, 'Plugging a Hole in the Ocean: The Emerging Science of Marine Reserves' (2003) 13(1) Ecological Applications Supplement S3. 
Miller G, 'Ecosystem Management: Improving the Endangered Species Act' (1996) 6 Ecological Applications 715 .

Morrissey WA, 'Science Policy and Federal Ecosystem-Based Management' (1996) 6 Ecological Applications 717.

Murawski SA, 'Ten Myths Concerning Ecosystem Approaches to Marine Resource Management' (2007) 31 Marine Policy 681.

Norse EA, 'Ecosystem-Based Spatial Planning and Management of Marine Fisheries: Why and How?' (2010) 86(2) Bulletin of Marine Science 179.

Pala C, 'Giant Marine Reserves Pose Vast Challenges' (2013) 339 Science 640.

Patlis J and others, 'The National Marine Sanctuary System: The Once and Future Promise of Comprehensive Ocean Governance' 44 Environmental Law Reporter (2014) 10932.

Pendleton LH and others, 'Debating the Effectiveness of Marine Protected Areas' (2017) 75(3) ICES Journal of Marine Science 1156.

Pikitch E and others, 'Ecosystem-Based Fisheries Management' (2004) 305 Science 346.

Pitcher TJ and others, 'An Evaluation of Progress in Implementing Ecosystem-Based Management of Fisheries in 33 Countries' (2009) 33 Marine Policy 223.

Rice J, 'Managing Fisheries Well: Delivering the Promises of and Ecosystem Approach' (2011) 12 Fish and Fisheries 209.

Reiter MA and others, 'An Integrated Framework for Informing Coastal and Marine Ecosystem Management Decisions' (2013) 15:1 Journal of Environmental Assessment Policy and Management.

Rosenberg A and others, 'Ecosystem Approaches to Fishery Management Through Essential Fish Habitat' (2000) 66 Bulletin of Marine Science 535 .

Ruckelshaus M and others, 'Marine Ecosystem-based Management in Practice: Scientific and Governance Challenges' (2008) 58(1) BioScience 53.

Ruckelshaus M and others, 'Securing Ocean Benefits for Society in the Face of Climate Change' (2013) 40 Marine Policy 154.

Samhouri JF and others, 'Lessons Learned from Developing Integrated Ecosystem Assessments to Inform Marine Ecosystem-Based Management in the USA' (2014) 71(5) ICES Journal of Marine Science 1205.

Samhouri JF and others, 'Using Existing Scientific Capacity to Set Targets for Ecosystem-Based Management: A Puget Sound Case Study' (2011) 35 Marine Policy 508.

Sievanen L and others, 'Linking Top-Down and Bottom-Up Processes Through the New US National Ocean Policy' (2011) 4 Conservation Letters 298.

Shugart-Schmidt KSP and others, 'SeaStates G20 2014: How Much of the Seas Are G2o Nations Really Protecting?' (2015) 25 Ocean and Coastal Management 115. 
Squillace MS and others, 'Essay: Presidents Lack the Authority to Abolish or Diminish National Monuments' (2017) 103 Virginia Law Review Online 55.

Tallis H and others, 'The Many Faces of Ecosystem-Based Management: Making the Process Work Today in Real Places' (2010) 34 Marine Policy 340.

Turnipseed M and others, 'Policy Forum: Legal Bedrock for Rebuilding America's Ocean Ecosystems' (2009) 324 Science 183.

Wagner FH, 'Whatever Happened to the National Biological Survey?' (1999) 49 BioScience 219 .

Witherell, C, Pautzke C and Fluharty D, 'An Ecosystem Based Approach for Alaska Groundfish Fisheries' (2000) 57 ICES Journal of Marine Sciences 771.

\section{Other Sources}

Environmental Law Institute, Ocean and Coastal Ecosystem-Based Management: Implementation Handbook (Environmental Law Institute 2009) < www.eli.org/sites/ default/files/eli-pubs/d19_03.pdf> accessed 1 October 2018.

Environmental Law Institute, Marine Spatial Planning in US Waters: An Assessment and Analysis of Existing Legal Mechanisms, Anticipated Barriers, and Future Opportunities (Environmental Law Institute for Ocean Conservancy 2009).

Fitzsimmons AK, Federal Ecosystem Management: A 'Train Wreck' in the Making (Cato Institute Policy Analysis No. 217, Cato Institute 1994) <www.cato.org/publications/ policy-analysis/federal-ecosystem-management-train-wreck-making > accessed December 10, 2017.

Peet KR, 'Documenting and Evaluating a New Approach to Establishing Large-Scale.

Marine Protected Areas in the U.S.' Thesis Masters of Marine Affairs, School of Marine and Environmental Affairs, University of Washington, Seattle, Washington, UsA 2014.

West Coast Regional Planning Body, 'Agenda December 5-6, 2017' <www.westcoast marineplanning.org> accessed 1 October 2018. 